Review

\title{
Phosphodiesterases and Compartmentation of cAMP and cGMP Signaling in Regulation of Cardiac Contractility in Normal and Failing Hearts
}

\author{
Gaia Calamera (D), Lise Román Moltzau (D), Finn Olav Levy (D) and Kjetil Wessel Andressen *(D)
}

Citation: Calamera, G.; Moltzau, L.R.; Levy, F.O.; Andressen, K.W.

Phosphodiesterases and

Compartmentation of cAMP and cGMP Signaling in Regulation of Cardiac Contractility in Normal and Failing Hearts. Int. J. Mol. Sci. 2022, 23, 2145. https://doi.org/10.3390/ ijms23042145

Academic Editors: Mauro Giorgi, Manuela Pellegrini and

Mara Massimi

Received: 27 January 2022

Accepted: 11 February 2022

Published: 15 February 2022

Publisher's Note: MDPI stays neutral with regard to jurisdictional claims in published maps and institutional affiliations.

Copyright: (C) 2022 by the authors. Licensee MDPI, Basel, Switzerland. This article is an open access article distributed under the terms and conditions of the Creative Commons Attribution (CC BY) license (https:// creativecommons.org/licenses/by/ $4.0 /)$.
Department of Pharmacology, Institute of Clinical Medicine, Oslo University Hospital, University of Oslo, P.O. Box 1057 Blindern, 0316 Oslo, Norway; gaia.calamera@medisin.uio.no (G.C.);

1.r.moltzau@medisin.uio.no (L.R.M.); f.o.levy@medisin.uio.no (F.O.L.)

* Correspondence: k.w.andressen@medisin.uio.no; Tel.: +47-22840372

\begin{abstract}
Cardiac contractility is regulated by several neural, hormonal, paracrine, and autocrine factors. Amongst these, signaling through $\beta$-adrenergic and serotonin receptors generates the second messenger cyclic AMP (cAMP), whereas activation of natriuretic peptide receptors and soluble guanylyl cyclases generates cyclic GMP (cGMP). Both cyclic nucleotides regulate cardiac contractility through several mechanisms. Phosphodiesterases (PDEs) are enzymes that degrade cAMP and cGMP and therefore determine the dynamics of their downstream effects. In addition, the intracellular localization of the different PDEs may contribute to regulation of compartmented signaling of cAMP and cGMP. In this review, we will focus on the role of PDEs in regulating contractility and evaluate changes in heart failure.
\end{abstract}

Keywords: cardiomyocyte; inotropic response; lusitropic response; beta-adrenergic receptor; GC-A; GC-B; ANP; BNP; CNP; 5-HT4

\section{Introduction}

Phosphodiesterases (PDEs) are the enzymes that degrade both cyclic adenosine $3^{\prime}, 5^{\prime}$ monophosphate (cAMP) and cyclic guanosine $3^{\prime}, 5^{\prime}$-monophosphate (cGMP) to nucleoside phosphates (5'AMP and $5^{\prime} \mathrm{GMP}$, respectively). PDEs are categorized in 11 families with subfamilies and splice variants [1]. Based on the different affinities and activities towards cAMP and cGMP, they can be classified as cAMP-selective (PDE4, 7 and 8), cGMP-selective (PDE5, 6 and 9), and dual substrate (PDE1, 2, 3, 10, and 11) PDEs. PDE1-5 and 8-10 are expressed in the heart [2,3]. All PDEs contain a conserved catalytic domain and a variable N-terminal domain. Cyclic nucleotides or PDE inhibitors bind the catalytic site, and differences in single amino acids at this binding site allow development of selective inhibitors for PDE isoforms. The N-terminal region, instead, determines regulation and localization of the enzyme [2].

In this review, we focus on the role of PDEs in regulating cardiac contractility (Figure 1). After covering cardiac contractility and its modulation by cAMP and cGMP, we will discuss in turn the role of the PDEs that are selective for cAMP, the cGMP-selective PDEs and finally the PDEs that can hydrolyze both cAMP and cGMP. Lastly, we will examine some important aspects related to PDEs and contractility, such as changes in PDE function in heart failure and their role in orchestration of cAMP/cGMP signaling in nanodomains. 


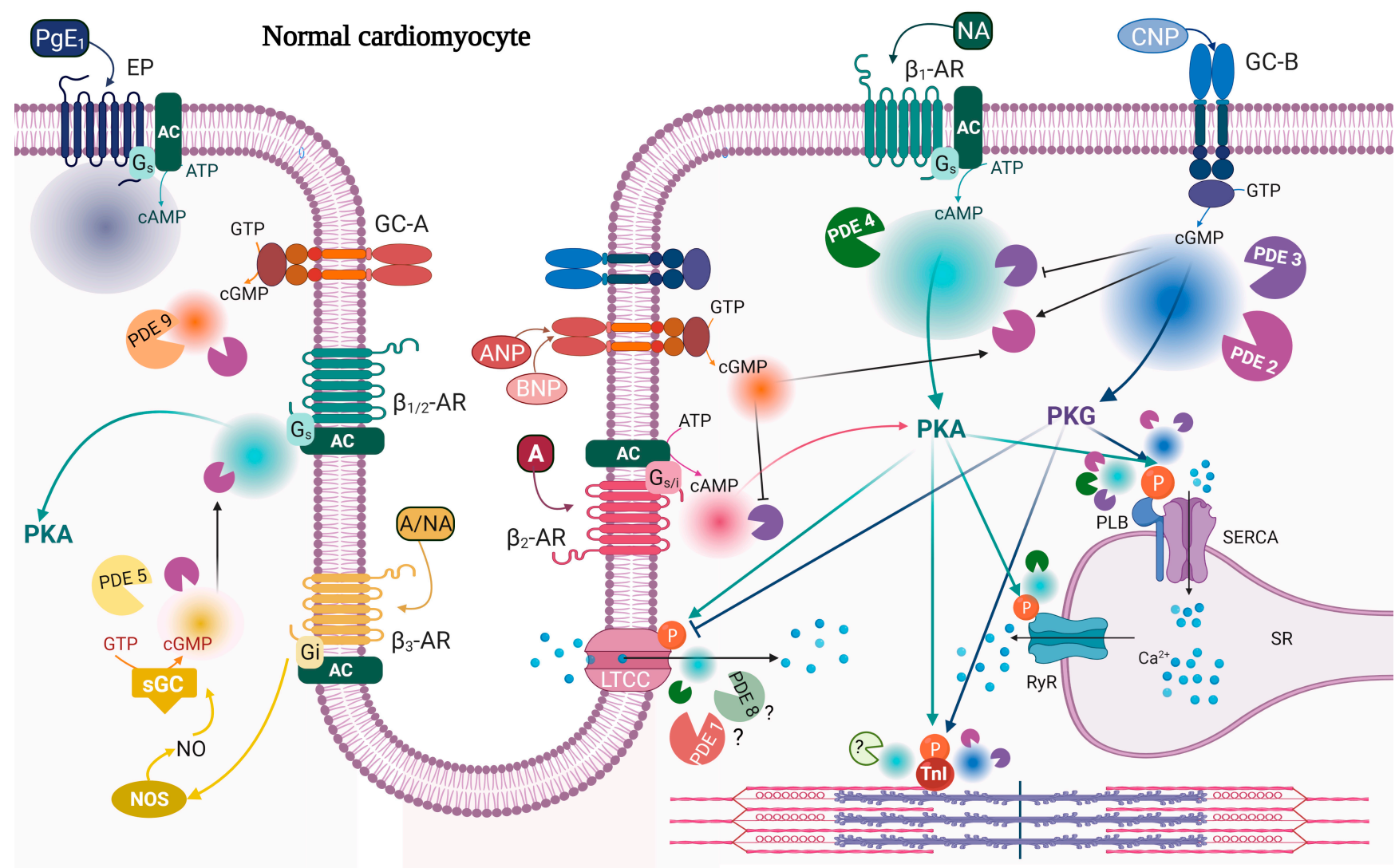

Figure 1. cAMP/cGMP signaling and PDEs modulating contractility in normal cardiomyocytes. $\beta_{1}$-AR stimulation causes a widespread rise in cAMP (cyan), which activates PKA phosphorylation of PLB, TnI, RyR, and LTCC. These events together lead to a positive inotropic response and a positive lusitropic response. Global and localized cAMP pools are under the control of PDE2 (purple), PDE3 (violet), and PDE4 (dark green) activity. $\beta_{2}$-AR stimulation increases cAMP (pink), degraded by PDE2, and which affects contractility, but to a lower extent compared to $\beta_{1}$-AR stimulation. CNP stimulation of GC-B gives a widespread increase in CGMP (blue) and PKG activation; PKG phosphorylates PLB and TnI and decreases LTCC current. These events contribute to a negative inotropic response and a positive lusitropic response. Global and local cGMP are degraded by PDE2 and PDE3. ANP stimulation of GC-A triggers a more restricted cGMP pool (orange) which does not seem to have a major direct role in contractility, and it is under the control of PDE2 and PDE9. cAMP/cGMP cross-talk is illustrated with black arrows indicating cGMP activation of PDE2 or inhibition of PDE3 activity towards cAMP. $\beta_{3}$-AR stimulation can indirectly modulate contractility by increasing an NO-dependent cGMP pool which activates PDE2 and decreases $\beta_{1 / 2}$-AR-stimulated contractility. This pool of cGMP (yellow) is degraded by PDE2 and PDE5. Prostanoid receptors (EP) stimulated by prostaglandin $\mathrm{E}_{1}\left(\mathrm{PgE}_{1}\right)$ increase cAMP with no effect on contractility. Shown also are receptors demonstrated to be present in T-tubule. Question marks indicate either unknown PDE or that the function of that PDE is not clear. A, adrenaline; AC, adenylyl cyclase; ANP, atrial natriuretic peptide; ATP/GTP, adenosine/guanosine triphosphate; BNP, brain natriuretic peptide; cAMP/cGMP, cyclic adenosine/guanosine 3',5'-monophosphate; CNP, C-type natriuretic peptide; EP, prostanoid receptor; GC-A/B, guanylyl cyclase A/B; Gs/i, stimulatory/inhibitory G protein; LTCC, L-type calcium channel; NA, noradrenaline; NO, nitric oxide; NOS, nitric oxide synthases; $\mathrm{p}$, indicates phosphorylation; PDE, phosphodiesterase; $\mathrm{PgE}_{1}$, prostaglandin $\mathrm{E}_{1}$; $\mathrm{PKA} / \mathrm{PKG}$, protein kinase A/G; RyR, ryanodine receptor; SERCA, sarcoendoplasmic reticulum (SR) calcium ATPase; sGC, soluble guanylyl cyclase; TnI, troponin I; $\beta$-AR, beta-adrenergic receptor. Created with BioRender.com, accessed on 7 February 2022. 


\section{Cardiac Contractility}

Cardiomyocytes are the key players in cardiac contraction and relaxation. They contain contractile structures composed of the myofilaments, myosin and actin, organized in sarcomeric units. Along the myofilaments, actin monomers are localized with tropomyosin and the complex of troponin $\mathrm{T}$, troponin $\mathrm{I}$, and troponin $\mathrm{C}$ ( $\mathrm{TnT}, \mathrm{TnI}$, and $\mathrm{TnC}$, respectively) [4]. Electric excitation of the sarcolemma initiates cardiac contraction through the process of excitation-contraction coupling, mediated by changes in cytosolic calcium levels [5]. Depolarization of cardiomyocytes triggers opening of L-type $\mathrm{Ca}^{2+}$ channels (LTCC) and influx of extracellular $\mathrm{Ca}^{2+}$, which in turn triggers the opening of ryanodine receptors (RyR) in the sarcoplasmic reticulum (SR) that release $\mathrm{Ca}^{2+}$ into the cytosol. Intracellular $\mathrm{Ca}^{2+}$ binds to $\mathrm{TnC}$, leading to a conformational change and binding to TnI; this in turn moves its inhibitory domain away from actin and promotes the displacement of tropomyosin, leaving the actin surface free to bind the myosin heads. Together, these conformational changes lead to formation of cross-bridges along the myosin and actin myofilaments. When the cross-bridges are formed, ATP binds to myosin. Its hydrolysis brings the myosin heads to produce the power stroke, and the myofilaments will slide past each other. This triggers muscle shortening and ultimately contraction of the heart, called systole. Following contraction, cytosolic $\mathrm{Ca}^{2+}$ is efficiently removed and the cytosolic $\mathrm{Ca}^{2+}$ levels drop, due primarily to the activity of the sarcoplasmatic reticulum $\mathrm{Ca}^{2+}$-ATPase (SERCA) and the sarcolemmal $\mathrm{Na}^{+} / \mathrm{Ca}^{2+}$ exchanger, but also the sarcolemmal ATPase and the mitochondrial $\mathrm{Ca}^{2+}$ uniporter. As calcium levels drop, calcium bound to $\mathrm{TnC}$ is released, and $\mathrm{TnI}$ and tropomyosin are returned to a closed state that prevents actin from interacting with myosin. Thus, relaxation of the heart (diastole) can occur [5]. The efficiency of cardiac excitation-contraction coupling and $\mathrm{Ca}^{2+}$ removal as well as the contractile proteins themselves are regulated by, e.g., cAMP and cGMP, mainly by phosphorylation of proteins involved in $\mathrm{Ca}^{2+}$ handling, such as LTCC, RyR, and the SERCA-inhibiting protein phospholamban (PLB), and sarcomeric proteins, such as TnI, myosin binding protein $\mathrm{C}$ (MyBP-C), and titin. Effects that enhance contractility, i.e., the ability of the heart to contract, are called (positive) inotropic effects, whereas effects that enhance cardiac relaxation are called (positive) lusitropic effects.

\section{Cyclic Nucleotide Signaling and Contractility}

Cyclic AMP is a second messenger synthetized by adenylyl cyclase (AC) that can be activated in response to stimulation of G-protein-coupled receptors (GPCRs) coupled to the AC-stimulating $\mathrm{G}$ protein $\mathrm{G}_{\mathrm{s}}$. $\mathrm{G}_{\mathrm{i}}$-coupled GPCRs, on the other hand, activate the inhibitory $G$ protein $G_{i}$ that inhibits AC activity. Cyclic AMP activates several effector proteins, such as protein kinase A (PKA), exchange proteins directly activated by cAMP (Epac1 and Epac2), cyclic nucleotide-gated ion channels (CNGCs), and Popeye-domain-containing proteins, which regulate a vast array of downstream processes. PKA, as the most important cAMP-activated effector in regulation of contractility, is spatially localized and regulated by a family of scaffolding proteins termed A Kinase Anchoring Proteins (AKAPs). AKAPs anchor PKA to its target and the complexes often include PDEs responsible for regulating local cAMP levels, and phosphatases to tightly regulate PKA-mediated phosphorylation [6-12].

Cyclic GMP is synthesized by soluble guanylyl cyclase (sGC), activated by nitric oxide (NO), which is in turn synthesized by nitric oxide synthases (NOS); particulate guanylyl cyclases (GCs) can also synthesize cGMP when activated by the natriuretic peptides (NP) atrial natriuretic peptide (ANP), brain natriuretic peptide (BNP), and C-type natriuretic peptide (CNP) [13]. Increase in cGMP by NO/sGC activation can also occur via stimulation of $\beta_{3}$-AR [14]. In order to mediate its downstream effects, cGMP activates CNGCs and protein kinase $\mathrm{G}(\mathrm{PKG})$, which can phosphorylate several targets $[15,16]$.

Cyclic AMP and cGMP activation of PKA and PKG, respectively, modulates contractility through phosphorylation of several proteins. PKA phosphorylation of LTCC and RyR increases their open probability and therefore increases cytosolic calcium levels. Together, this generates a positive inotropic response (PIR). Cyclic AMP also mediates a lusitropic 
response (LR) through PKA phosphorylation of PLB and TnI. Phosphorylation of PLB removes its inhibitory tone on the SERCA pump, which results in increased pumping of $\mathrm{Ca}^{2+}$ into the SR. Phosphorylation of TnI, on the other hand, reduces the sensitivity of the myofilaments for binding $\mathrm{Ca}^{2+}$, thus allowing faster $\mathrm{Ca}^{2+}$ dissociation. Together, this results in a faster relaxation (lusitropic response) [5]. In situations where cytosolic $\mathrm{Ca}^{2+}$ is not limiting, as under cAMP stimulation, PLB phosphorylation will also contribute to a positive inotropic effect through increasing $\mathrm{SR} \mathrm{Ca}^{2+}$ content. PKG can also phosphorylate PLB and TnI, causing a LR similar to PKA phosphorylation [17-24]. However, contrarily to PKA, PKG phosphorylation of LTCC seems to decrease calcium influx. Thus, due to decreased $\mathrm{Ca}^{2+}$ availability due to phosphorylation of PLB and LTCC, combined with TnI phosphorylation, PKG activation is mostly associated with a negative inotropic response (NIR) [25-29]. PKG can also phosphorylate RyR, but no alteration of cardiac RyR activity has been reported $[30,31]$. Thus, under cGMP stimulation, cytosolic $\mathrm{Ca}^{2+}$ may be limiting due to lack of LTCC stimulation, and PLB phosphorylation will mainly contribute to a NIR [23].

\section{4. cAMP-Selective PDEs and Compartmentation of cAMP Signaling Regulating Contractility}

Intracellular signaling mediated by cyclic nucleotides (CNs) is organized in spatialtemporal nanodomains defined by localization and activities of receptors, adenylyl or guanylyl cyclases, protein kinases and PDEs, and this is defined as compartmentation. The first evidence for compartmentation of second messenger signaling in the heart was published in the 1970s and early 1980s for cAMP, where it was observed that isoproterenol (Iso) stimulation of $\beta$-ARs increased contractility, while stimulation with the prostaglandin $\mathrm{PgE}_{1}$ did not, despite both increasing cAMP [32-34]. It was shown that this difference was related to the intracellular location where cAMP was increased; Iso-stimulated cAMP pools were found in both the soluble and particulate fraction of cardiomyocyte homogenates, whereas cAMP from $\operatorname{PgE}_{1}$ was found only in the soluble fraction $[35,36]$.

The GPCR $\beta_{1}$-adrenergic receptor ( $\beta_{1}$-AR) is the main $\beta$-AR in cardiomyocytes. Stimulation of these receptors activates $G_{s}$ that activates ACs, of which AC5 and AC6 are the main isoforms expressed in the heart [37]. Increased cAMP activates PKA that induces a PIR and a LR [38]. $\beta_{2}$-ARs represent a smaller portion of ARs in the heart and also activate $\mathrm{G}_{\mathrm{s}}$ (as $\beta_{1}$-AR). Whereas $\beta_{2}$-AR stimulation can trigger a PIR, its ability to trigger a LR was disputed [39], although later studies have reported a small LR [40]. The reduced LR might be due to the reported ability of $\beta_{2}$-ARs to activate both $G_{s}$ and $G_{i}$ but may also be related to the receptor localization. In this regard, $\beta_{2}$-ARs are found in the T-tubules, and thereby specifically regulate LTCC current [41], while $\beta_{1}$-AR stimulation produces cAMP both in the T-tubules and at the cell crest [42-48]. Therefore, $\beta_{2}$-AR signaling seems very restricted, while the $\beta_{1}$-AR-stimulated cAMP can diffuse more throughout the cell and reach multiple targets. Similar to $\beta$-AR signaling, the serotonin $5-\mathrm{HT}_{4}$ receptors can also give an increase in CAMP and a PIR, at least in failing hearts [49-53].

Cyclic AMP compartments relevant for contractility are regulated by several PDEs. Amongst the cAMP-selective PDEs in the heart, PDE4 is the main PDE, whereas little is known about PDE8.

\subsection{PDE4}

PDE4 is a cAMP-selective PDE with a low $\mathrm{K}_{\mathrm{m}}(1.2-10 \mu \mathrm{M})$. It comprises a family of 20 isoforms encoded by PDE4A, B, C, and D genes, of which all except PDE4C are found in the heart $[1,54]$. The $\mathrm{N}$-terminal region is characterized by upstream conserved regions 1 and 2 (UCR1 and UCR2), which vary between the isoforms and confer them different functional roles and specific subcellular localizations [55-60]. When comparing PDE4 activity between rodent and human hearts, many similarities were found, including a rather similar activity [61]. However, due to higher non-PDE4 activities in human heart, PDE4 is responsible for only $\sim 10 \%$ of the total cAMP-PDE activity in failing human heart 
vs. $\sim 50 \%$ in normal and failing rat heart $[40,61-64]$. This difference implies that data on PDE4 from rodents cannot be applied directly to human myocardium. In this regard, a study on ventricular trabeculae from human failing hearts from patients treated with beta-blockers, either metoprolol [65] or carvedilol [66], showed that inhibiting PDE4 did not affect $\beta_{1} / \beta_{2}$-AR mediated contractility, while inhibition of PDE3 did. However, also in human failing myocardium, whereas PDE4 inhibition alone had no effect, a role of PDE4 inhibition in enhancement of a $5-\mathrm{HT}_{4}$-mediated positive inotropic response to serotonin was revealed in the presence of PDE3 inhibition [52]. On a similar note, a study in human atrial myocardium revealed a role of PDE4 in controlling arrhythmias when both PDE4 and PDE3 were inhibited [63]. This suggests a role of PDE4 that is secondary to PDE3 in regulating contractility in human heart.

In rodents, PDE4 is the main PDE responsible for hydrolysis of cAMP, when measuring cAMP levels, and together with PDE3 regulates $\beta$-AR-stimulated contractility $[40,61,63,67-70]$. The importance of PDE4 regulating $\beta_{1}$-AR-mediated PIR and LR, has been reported in both atria and ventricle $[40,71,72]$. For $\beta_{2}$-AR-mediated contractility, there are regional differences in the heart, where PDE4 regulates contractility in the base but not the apex of the ventricle. This could be attributed to several factors, including more regular T-tubular organization and higher PDE4 activity at the base of the heart [73]. In one report using a cAMP biosensor targeted to PLB, $\beta$-AR-stimulation was sensitive to inhibition of PDE4 [74]. In another study using a different biosensor targeted to SERCA2A, PDE4 did not regulate $\beta_{2}$-AR-stimulated cAMP near PLB, whereas PDE2 and PDE3 did [75]. Taken together, this suggests that the $\beta_{1}$-AR is regulated by PDE4 near PLB. One study has also reported localization of PDE4 near PLB in human failing myocardium [61].

PDE4D3 forms a signalosome together with PKA and RyR regulating the SR-Ca ${ }^{2+}$ leak and in heart failure (HF) reduced local PDE4 gives increased phosphorylation of RyR and greater $\mathrm{Ca}^{2+}$ efflux from the SR [76]. Moreover, PDE4D seems to regulate the SR influx of $\mathrm{Ca}^{2+}$ by being part of a complex with SERCA, PKA, and PLB [77]. PDE4B is involved in the regulation of LTCC, which allows $\mathrm{Ca}^{2+}$ entrance in the cell when phosphorylated by PKA $[78,79]$. Recent work from the Nikolaev lab, using a novel biosensor located near RyR, showed that PDE4 was the main PDE responsible for degrading cAMP near RyR, and that this PDE4 activity is reduced in HF due to a redistribution of PDE4D leading to lower amounts associated with RyR [80]. This could contribute to the altered PDE4 regulation of contractility in HF [40].

In some reports on human, porcine, and rodent cardiac ventricle, $\beta_{1}-\mathrm{AR}-, \beta_{2}-\mathrm{AR}-$, or 5- $\mathrm{HT}_{4}$-mediated contractility was not enhanced by inhibiting PDE4 alone, despite increased levels of cAMP. Rather, simultaneous inhibition of both PDE3 and PDE4 was needed to obtain an increased contractility, both in normal and failing hearts $[40,52,69,71,72,81-84]$. Also, upon 5- $\mathrm{HT}_{4}$ receptor stimulation, inhibition of both PDE3 and PDE4 significantly increased cAMP levels in porcine left atrium [85] and in human atrial cardiomyocytes, where the effect of PDE3 and PDE4 inhibition seemed more pronounced and thus was able to restore a blunted 5-HT response in cardiomyocytes from patients with persistent atrial fibrillation [86]. Together, this suggests that both PDE3 and PDE4 are responsible for regulating contractility and behave in a redundant manner. In support of PDE redundancy, using in silico modeling, Zhao et al. showed that under Iso-stimulation the most active PDE is PDE4, while PDE2 activity increased to a smaller degree and even smaller for PDE3. However, when PDE2 was inhibited, they showed that its activity dropped together with a rise in PDE4 activity. Similarly, when PDE4 was inhibited, increased PDE2 activity compensated for the loss in cAMP hydrolytic capacity [87].

\subsection{PDE8}

PDE8 is a cAMP-selective phosphodiesterase and has two isoforms: PDE8A and PDE8B [88]. The regulatory domain comprises a REC domain (similar to the "receiver" domains of bacterial two-component signaling systems) [89] and a PAS domain (an acronym for Period, Arnt, and Sim), however, little is known about the function of these regulatory 
domains [90]. PDE8 is expressed in cardiomyocytes, but its function is not completely understood. One study shows that PDE8A ${ }^{-/-}$cardiomyocytes have larger $\mathrm{Ca}^{2+}$ transients, increased LTCC current, and increased cardiomyocyte contractility upon $\beta$-AR activation, but also larger $\mathrm{Ca}^{2+}$ spark frequency in the absence of receptor activation [91]. This suggests alteration of excitation-contraction coupling through PDE8 inhibition. Since PDE8 is not sensitive to the widely used "general" PDE inhibitor IBMX, caution should be taken when interpreting studies with a lack of the IBMX effect, as there might still be a hidden effect of PDE8. For example, it was reported that $\beta_{1}$-AR caused a widespread cAMP signal, whereas $\beta_{2}$-AR caused a much more localized cAMP signal [45]. If this difference was, at least in part, due to cAMP degradation by PDEs, one would think that PDE inhibition should make the $\beta_{2}$-AR cAMP signal more similar to that of $\beta_{1}$-AR. However, the difference was insensitive to PDE inhibition by IBMX, which at the time would indicate that PDEs were not involved. However, an intriguing possibility is that PDE8 could be involved in the difference, and that PDE8 inhibition, maybe in addition to IBMX, would make the $\beta_{2}$-AR signal more like the $\beta_{1}$-AR signal.

\section{5. cGMP-Selective PDEs and Compartmentation of cGMP Signaling Regulating Contractility}

One of the first indications of cGMP compartmentation was seen in the early 1990s when cGMP from NO was found to be in both the soluble and the particulate fraction, while cGMP from the pGC was present only in the particulate fraction [92]. In rat hearts, NOdependent sGC activation does not modulate IR or LR [93-96], whereas CNP-stimulation of GC-B does [17-24,29,53,62,64,97,98]. In most studies the natriuretic peptides ANP and BNP activating GC-A show no effect on contractility $[17,18,24,29,53,62,98]$, except for a few studies showing a NIR $[20,28,99]$. This indicates that even though the particulate GCs (GC-A and GC-B) are both in the plasma membrane, somehow they still increase cGMP in different subcellular compartments. Nevertheless, ANP and BNP seem to mediate PKG phosphorylation of LTCC, thus decreasing the calcium current [25,27-29]. The natriuretic peptide CNP can elicit a NIR and a LR through PKG phosphorylation of PLB (leading to increased SERCA2 activity) and TnI, in normal rat and mouse hearts [17-24], but also in rat failing hearts $[23,29,64]$. In addition, an initial PIR has been reported and linked also to PLB phosphorylation and increase in PKG-mediated calcium transients $[18,19,23,100]$. However, the mechanism behind this initial PIR is not completely understood. It could be due to phosphorylation of PLB happening as a first step, which would increase cytosolic calcium sequestration in the SR, and therefore promoting the next contraction cycle. This would imply a delay in TnI phosphorylation by PKG, which then gives the NIR. Alternatively, cGMP increase could initially inhibit PDE3 and increase cAMP-mediated contractility (see "Dual-substrate PDEs and compartmentation of cyclic nucleotide signaling regulating contractility"), followed slightly later by PKG phosphorylation of the downstream targets, which could overcome the initial PIR and elicit a NIR. These speculations, however, would require further investigation. CNP is found to reduce LTCC current in failing and normal cardiomyocytes through activation of PKG [26,29]; this might contribute to the NIR, but additional mechanisms must be involved as BNP, also reducing LTCC current, does not induce a NIR [29].

The PDEs that selectively hydrolyze cGMP in the heart are PDE5 and PDE9.

\subsection{PDE5}

PDE5 selectively degrades cGMP and has three isoforms (PDE5A1-3) expressed in human hearts [101]. The regulatory domain contains two GAF (cGMP-binding PDEs, Anabaena adenylyl cyclase, and Escherichia coli Fh1A) domains and a phosphorylation site. Cyclic GMP binds to the GAF-A domain with high affinity, causing an allosteric increase in enzymatic activity. The enzymatic activity and thus cGMP degradation is also increased by phosphorylation of PDE5 by PKG [102]. In adult cardiomyocytes, PDE5 is expressed at low levels and localizes to the Z-disc where it degrades cGMP mainly from the 
NO/sGC pathway [103-105]. In unstimulated cells, using an untargeted FRET biosensor, PDE5 shows low activity towards cGMP $[24,106]$.

Inhibiting PDE5 does not affect basal contractility. However, when activating all three $\beta$-ARs, PDE5 inhibition (by sildenafil) reduced contractility in normal mouse heart involving increase in NOS3-NO-sGC-originated cGMP [97,103], as well as in human healthy volunteers [107]. In order to elucidate the signaling behind the negative effect of sildenafil on contractility, Isidori et al. showed that consequent cGMP augmentation led to activation of PDE2 and thus decrease in cAMP levels; this was associated with decreased $\beta_{2}$-ARmediated contractility after PDE5 inhibition [108]. In addition, Schobesberger et al. showed that PDE5 regulated a cGMP-pool generated by NOS3-sGC activation subsequent to $\beta_{3}$-AR activation, at caveolae-enriched membrane fractions in T-tubules. This cGMP pool was then responsible for a decrease in cAMP levels through PDE2 activation [109]. These data fit with previous data where $\beta_{3}$-ARs were found to elicit a NIR and positive LR via eNOS and cGMP $[14,110]$. In a chronic HF model, a role of PDE5 in regulating contractility was revealed only after simultaneous PDE3 inhibition, which increased the maximal NIR to $\mathrm{CNP}$, indicating a redundancy between these two PDEs [64].

\subsection{PDE9}

PDE9A is the PDE with the lowest $K_{m}$ for cGMP $(0.70-0.17 \mu \mathrm{M})$ and it was recently discovered to be expressed in the heart, localized to the SR (but not Z-disc, where PDE5 was located), and regulating cGMP generated after GC-A stimulation, but not from stimulating sGC $[2,105]$. Moreover, PDE9 is localized in the mitochondria in cardiomyocytes [111]. We are not aware of any literature where PDE9 inhibition regulates cGMP-mediated contractility. However, the availability of novel PDE9 inhibitors may clarify whether PDE9 regulates inotropic and lusitropic responses.

\section{Dual-Substrate PDEs and Compartmentation of Cyclic Nucleotide Signaling Regulating Contractility}

Although the cAMP- and cGMP-pathways modulate contractility differently, as described above, increased concentrations of cGMP can also modulate cAMP levels, by affecting the activity of certain PDEs. Cyclic GMP binds to a GAF domain on PDE2 to increase the enzymatic activity, and thereby reducing cAMP responses, whereas at PDE3 cGMP is hydrolyzed slowly and this inhibits cAMP degradation, increasing cAMP-mediated responses. Thereby, PDEs that can hydrolyze both cAMP and cGMP are responsible for so-called cross-talk between the two signaling pathways. The compartments relevant in contractility that involve such cross-talk are not easy to differentiate from the specific cAMP/cGMP compartments described above. Further investigation with focus on local cyclic nucleotide fluctuations and on how subcellular compartmentation occurs, will help to resolve this.

The dual-substrate PDEs also have important roles towards the two single pathways, and in the next section, we describe how PDE1, PDE2, and PDE3 contribute to modulate contractility by regulating either cAMP or cGMP separately, but also how they modulate contractility by creating cGMP/cAMP cross-talk.

\subsection{PDE1}

The PDE1 family includes the isozymes PDE1A, PDE1B, and PDE1C [112]. These are $\mathrm{Ca}^{2+} /$ calmodulin (CaM)-dependent enzymes and their regulatory domain contains two $\mathrm{CaM}$ binding sites, two phosphorylation sites, and an inhibitory region, which retains the enzyme in its inactive configuration when the calcium levels are low [113,114]. CaM binding to PDE1 elevates its activity, whereas phosphorylation by PKA or CaMKII reduces the affinity for $\mathrm{Ca}^{2+} / \mathrm{CaM}$ and therefore its activation [115,116]. PDE1 enzymes can hydrolyze both cAMP and cGMP. PDE1A and PDE1B catalyze cGMP degradation with higher $\mathrm{K}_{\mathrm{m}}$ than for CAMP, while PDE1C has equal affinity [112]. Among the three isoforms, PDE1A and PDE1C are found in the heart. However, PDE1C is the predominant isoform in the 
human heart and specifically localizes to the $\mathrm{M}$ and $\mathrm{Z}$ lines in cardiomyocytes, while PDE1A is the predominant isoform in mice and rats [117-119]. Expression of PDE1 was increased in failing hearts $[119,120]$.

Most studies report data on the functional role of PDE1 in rodent hearts and do not investigate its specific effect on contractility. Recently, the group of David Kass has shown the role of PDE1C in rabbit and dog hearts, which, similar to human hearts, express predominantly this isoform and show positive inotropic and chronotropic effects after inhibiting PDE1. These effects are due to PDE1C activity over a soluble AC-cAMP nanodomain that regulates LTCC current via PKA, but does not involve modulation of SERCA current, phosphorylation of PLB, TnI, and myosin binding protein C, like in the $\beta$-AR-mediated contractility $[119,121]$.

\subsection{PDE2}

PDE2 is a dual substrate phosphodiesterase with similar high $V_{\max }$ and high $\mathrm{K}_{\mathrm{m}}$ for both cAMP and cGMP $[122,123]$. The isoform PDE2A has three splice variants that have either soluble (PDE2A1) or particulate (PDE2A2, PDE2A3) distribution [122-126]. PDE2 is found in human hearts [127] and in cardiomyocytes it localizes in the cytosol, plasma membrane, sarcomeric Z line, mitochondria, and nuclei [110].

The regulatory region contains two GAF domains, A and B [128]. Cyclic GMP binding to the GAF-B domain raises the esterase activity for both cAMP and cGMP [129]. Thus, this PDE is a key factor in the CGMP/cAMP cross-talk signaling and in the regulation of cardiac contractility [130].

\subsubsection{PDE2 Regulation of cAMP Relevant for Contractility}

In rat and mouse cardiomyocytes PDE2 contributes to a low fraction of the total cellular cAMP-PDE activity [64,110], while in humans with HF, it contributes $\sim 25 \%$ of the total cAMP-PDE activity [61]. There is solid evidence that PDE2 has a relevant role in modulating $\beta$-AR-stimulated cAMP pools. Accordingly, PDE2 inhibition increases LTCC currents and contractility, both in the absence and presence of $\beta$-AR-stimulation $[67,131,132]$. However, in other studies PDE2 inhibition did not influence basal or $\beta$-AR-elevated global cAMP, LTCC currents, or inotropic response $[40,133]$. In HF, PDE2 inhibition increased LTCC currents and sarcomere shortening in the absence and presence of $\beta$-AR stimulation [134]. In mice expressing either an untargeted or PLB-targeted cAMP sensor, PDE2 limits $\beta$-ARstimulated cAMP both in the whole cell and in the compartment surrounding PLB and the activity was increased around PLB in a mild hypertrophic model [74].

\subsubsection{PDE2 Regulation of cGMP Relevant for Contractility}

Total cGMP levels seem to be mainly controlled by PDE2 both in normal [106] and failing hearts [64]. However, when using an untargeted FRET biosensor in cardiomyocytes stimulated with CNP, PDE2 inhibition gave a smaller increase in cGMP compared to PDE3 inhibition [24]. Instead, PDE2 restricts ANP-stimulated cGMP which is localized at the T-tubules preventing far-reaching signals [104,135]. Accordingly, it seems that PDE2 activity is relevant in restricted compartments, in line with the observation that PDE2 inhibition increased CNP-stimulated cGMP levels measured by targeted biosensors near PLB and TnI [24]. Regulation of TnI and PLB is linked to modulation of the LR and in normal heart PDE2 also regulates CNP-induced LR, similarly to PDE3, since inhibition of either PDE resulted in a sensitized response [24]. In a rat HF model, PDE2 inhibition desensitized the CNP-induced NIR but had no effect on the lusitropic response [64].

\subsubsection{PDE2 and cGMP/cAMP Cross-Talk Relevant for Contractility}

Considering that PDE2 is a dual substrate PDE, and that cGMP can bind to the PDE2GAF domain and increase its enzymatic activity, the role of PDE2 in cGMP/cAMP cross-talk has been investigated. Specifically, cGMP-increase after sGC stimulation reduces LTCC current through activation of PDE2 and this is mediated by a decrease in cAMP and PKA 
phosphorylation of LTCC [133,136-138]. Activation of PDE2 by cGMP from sGC is also responsible for decreased contractility after $\beta_{1}$ - and $\beta_{2}$-AR activation [133], and such effect seems to derive from local cGMP increases in nanodomains defined by PKA RII-cAMP biosensors [139]. Mongillo et al. investigated cGMP/cAMP cross-talk by examining the role of all three $\beta$-ARs in adult cardiomyocytes. They showed that such stimulation involves a mechanism where activated $\beta_{3}$-ARs trigger NO release and consequent cGMP augmentation and that these pools of cGMP are responsible for PDE2 activation and thereafter reduction in $\beta_{1}$ - and/or $\beta_{2}$-AR-stimulated cAMP levels and PIR [110]. Supporting this mechanism, Schobesberger et al. further confirmed the localization of $\beta_{3}$-ARs in the caveolae and the related cGMP pools in the T-tubules, which are locally regulated mostly by PDE2 and PDE5 [109], and stimulation by NO-donor after $\beta$-AR-stimulation further decreased global cAMP levels in HF [134].

CNP can also, through cGMP-mediated activation of PDE2, decrease cAMP levels and thereby decrease $\beta$-AR-stimulated LTCC current [138,140]. Even though GC-A-stimulated cGMP microdomains seem to act differently than those stimulated by GC-B and do not seem to potentiate $\beta$-AR-stimulation of the cAMP pathway in several studies $[53,62,98,106]$, some studies reported that GC-A stimulation can either reduce $\beta$-AR-mediated cAMP via PDE2 activation in nanodomains defined by a PKA RII-targeted biosensor [139] or increase the $\beta$-AR-mediated contractile effects in a mild hypertrophic model after TAC (transverse aortic constriction) [141]. Real-time measurements of cAMP levels with a caveolin-targeted biosensor indicated a reorganization of PDE2 and PDE3 between $\beta_{1}$ - and $\beta_{2}$-AR compartments, revealing an ANP-induced increase of the positive inotropic effect of $\beta$-adrenergic stimulation in a mild hypertrophic model through PDE3 inhibition [141]. In this model, PDE2 activity was reduced around the $\beta_{1}$-AR microdomain and increased around the $\beta_{2}$-AR microdomain, therefore, ANP-stimulated cGMP will switch from reducing cAMP levels via PDE2 activation (in physiological conditions) to increase cAMP levels via PDE3 inhibition (in a disease model) relatively to the $\beta_{1}$-AR microdomain [141].

\subsection{PDE3}

PDE3 has two isoforms, PDE3A and PDE3B, both expressed in the heart [142-144]. PDE3 hydrolyzes both cAMP and cGMP with similar high affinities $\left(\mathrm{K}_{\mathrm{m}} \mathrm{cAMP} 0.16 \mu \mathrm{M} ; \mathrm{K}_{\mathrm{m}}\right.$ cGMP $0.09 \mu \mathrm{M}$ ), while the $\mathrm{V}_{\max }$ is $>10$-fold higher for cAMP. Hence, when cGMP binds, it is hydrolyzed slowly and this inhibits cAMP degradation $[1,145]$. The $\mathrm{N}$-terminal structure contains hydrophobic loops that allow for membrane insertion of the enzyme, and PDE3B is localized to T-tubule membranes while PDE3A is mainly found in SR membranes [146]. The latter forms a complex with SERCA, PLB, and AKAP18ס, and when PKA phosphorylates PDE3, cAMP hydrolysis is increased therein [147-149]. Consequently, PDE3A1 is regulating the cAMP-mediated regulation of $\mathrm{Ca}^{2+}$ re-uptake in the SR [67,149-151].

\subsubsection{PDE3 Regulation of cAMP Relevant for Contractility}

PDE3 is responsible for hydrolyzing global cellular cAMP levels in hearts from normal and HF animals, to a lower extent than PDE4, which is the main CAMP-PDE in rodents $[40,68,74]$. As mentioned previously, in humans PDE4 has a lower contribution to the total PDEs activity, and therefore PDE3 is the most important PDE degrading cAMP in human hearts [61,63,65]. Accordingly, PDE3 was found in the SR [152] and shown to be the main PDE regulating contractility in human atrium [153] and ventricle $[52,62,65,154]$. In rats, PDE3 is found to regulate both $\beta$-AR- and $5-\mathrm{HT}_{4}$ receptor-mediated PIR and LR $[40,52,98]$ and also regulates calcium transients in the absence and presence of $\beta$-AR stimulation and its inhibition causes an increase in sarcomere shortening [131,155].

Using targeted FRET-based biosensors, PDE3 subcellular activity was found to prevail around cAMP nanodomains defined by a PKA RI-targeted biosensor [139] and regulate $\beta_{2}$-AR signaling in caveolin-enriched compartments such as T-tubules [141]. However, in a mild hypertrophic model, PDE3 hydrolyzing activity towards $\beta_{2}$-AR-cAMP at the plasma membrane was reduced, with no changes in global expression, but with clear 
reduction in the caveolin-rich fractions [141]. Similarly, the role of PDE3 in the regulation of $\beta$-AR-mediated cAMP and LTCC current might prevail in hypertrophic compared to normal cardiomyocytes, due to reduced PDE4 activity [84]. Therefore, due to the apparent redundancy between PDE3 and PDE4, inhibiting both PDEs triggers a greater effect on basal, $\beta$-AR- and/or 5-HT 4 -receptor-induced cAMP levels, calcium, PIR and LR, compared to inhibiting either PDE alone $[40,52,69,84,156]$.

\subsubsection{PDE3 Regulation of cGMP Relevant for Contractility}

With regard to cGMP, PDE3 regulates global cellular cGMP levels and cytosolic cGMP measured by a non-targeted biosensor [106] and contractility, both in normal and failing hearts [24,64]. Using targeted FRET-based biosensors PDE3 was shown to constrain CNPstimulated cGMP at the plasma membrane, PLB, and myofilament compartments $[24,135]$. Inhibition of PDE3 increased the CNP-mediated LR in normal heart muscle, and the CNPmediated NIR and LR in HF models [24,64].

\subsubsection{PDE3 and cGMP/cAMP Cross-Talk Relevant for Contractility}

The natriuretic peptide CNP can modulate contractility by affecting cAMP signaling through cGMP-mediated inhibition of PDE3, causing a PIR mediated by $\beta_{1}$-AR and $\beta_{2}$-AR in normal and failing rat left ventricle $[53,62,98]$. 5-HT $\mathrm{HT}_{4}$ receptor-induced PIR was also shown to be increased by CNP-induced PDE3 inhibition in both failing rat left ventricle and in porcine left atrium $[53,81]$. In $\mathrm{HF}$, constitutive $\mathrm{NO} / \mathrm{sGC}$ activation increased 5- $\mathrm{HT}_{4}$-mediated PIR (through PDE3 inhibition), but also reduced $\beta_{1}$-mediated IR [53]. The reduction in $\beta_{1}$-mediated cAMP and IR by NO/sGC has been shown by others as discussed above under "PDE2 and cGMP/cAMP cross-talk relevant for contractility" $[103,109,110,133,134,139]$. The opposing effects of sGC stimulation on $\beta_{1}$-AR and $5-\mathrm{HT}_{4}$ receptors may indicate different compartmentation of PDEs in their signaling pathways. As also addressed above, ANP potentiated the $\beta$-AR-stimulated PIR, presumably through PDE3 inhibition in a mild hypertrophic model, but not in Sham [141]. However, in other studies GC-A stimulation did not affect $\beta_{1}$-AR-dependent contractility, neither in a chronic HF model nor in sham-operated animals [53,98].

\subsection{PDE10}

PDE10 is a dual PDE discovered in 1999 [157-159] and its role in the heart was only recently explored by Chen et al., where they showed upregulation of PDE10 in failing hearts and beneficial effects of PDE10 inhibition against hypertrophy and fibrosis. They also showed a restored contractile function in a mouse model of congestive HF, where the PDE10 gene is knocked down [3]. Therefore, it is not yet clear whether it directly regulates cardiac contractility.

\section{Modulation of PDEs in Heart Failure}

In HF the heart fails to provide adequate blood flow/pressure to meet the body's demands and this is associated with alterations in the cardiac structure, function, rhythm, and conduction. In HF, the body responds by activating compensatory mechanisms, such as salt and water retention, increase in noradrenaline and adrenaline (sympathetic activation), and increase in several hormones, such as angiotensin II, aldosterone, endothelin, and natriuretic peptides. Some of these changes will in the short term improve cardiac contractility and cardiac output, but in the long term some of these will worsen the prognosis $[160,161]$. Of these compensatory mechanisms, there are specific signaling pathways that regulate the beneficial and detrimental effects, and it is crucial to understand such signaling to improve $\mathrm{HF}$ treatment. Currently, $\mathrm{HF}$ is routinely treated with $\beta$-blockers, angiotensin converting enzyme (ACE) inhibitors/angiotensin receptor blockers (ARBs), mineralocorticoid receptor antagonists, sodium-glucose co-transporter 2 inhibitors and sometimes angiotensin receptor-neprilysin inhibitor, as well as diuretics when needed [162]. 
Despite the fact that cAMP and cGMP have many similarities in the signaling pathway and have similar protein targets, they can mediate different and sometimes opposite effects on contractility in the heart, as described above. In HF there is increased adrenergic activity stimulating $\beta$-ARs and increased natriuretic peptides. Long-term stimulation of $\beta$-AR is detrimental in chronic heart failure and $\beta$-blockers are a cornerstone in HF management $[162,163]$. Increasing cGMP, on the other hand, seems to be beneficial in the cardiovascular system and can mediate antifibrotic and antihypertrophic effects, vasodilation, natriuresis, and modulate cardiac contractility [164-169]. Stimulating sGC was protective against HF in mice [170], and in humans, stimulating sGC is beneficial in treatment of pulmonary arterial hypertension and HF with reduced Ejection Fraction (HFrEF) [171,172]. Inhibiting degradation of natriuretic peptides by the neprilysin inhibitor sacubitril showed improvements in HFrEF when administrated in combination with the angiotensin receptor blocker valsartan [173]. This drug combination was also shown to possibly improve HF with preserved Ejection Fraction (HFpEF) in certain subgroups [174]. In HFpEF, increased cardiac stiffness could impair diastolic filling. PKG phosphorylation of the structural sarcomeric protein titin decreases cardiac stiffness [175] and GC-B-stimulated cGMP increased titin phosphorylation and decreased cardiomyocyte stiffness in rat cardiomyocytes and during early phases of pressure overload in mice $[169,176]$. PKA also phosphorylates titin, reducing human cardiomyocyte stiffness, suggesting that increasing cAMP/PKA activation could have beneficial effects in HFpEF [177-179]. Taking these considerations together, modulation of PDEs that reduce cAMP levels but increase cGMP, could be a good strategy for HF treatment. However, in light of the different compartments regulating cardiac function, the reality is more complicated. In the following section, we discuss how PDEs change in HF and whether overexpression or inhibition of PDEs could represent possible pharmacological treatments (Figure 2; Table 1).

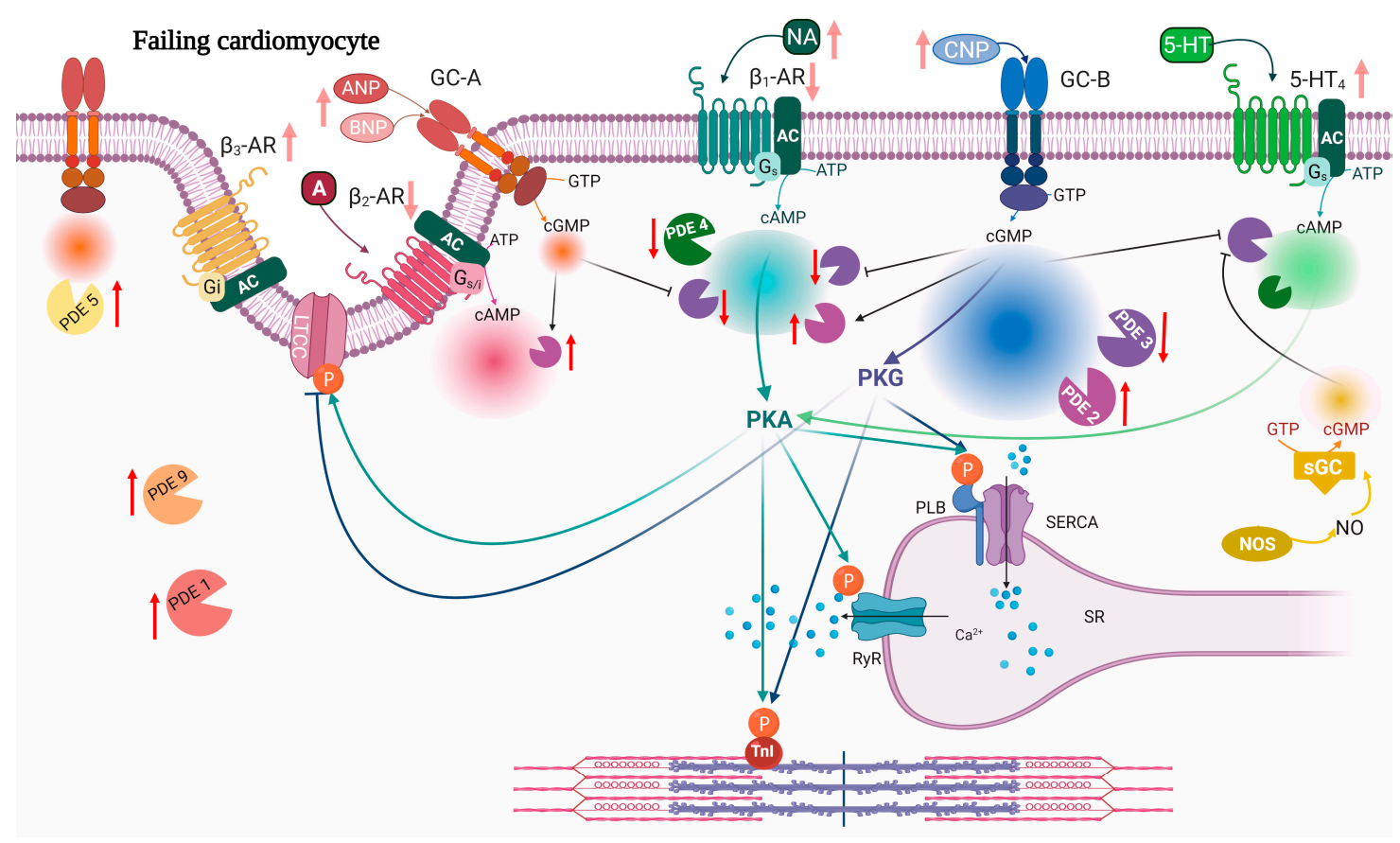

Figure 2. Remodeling and signaling alterations in heart failure. During HF, cardiomyocytes undergo structural remodeling which leads to alteration of the T-tubule structure, re-organization of the receptors and compartments. Red arrows indicate changes in expression of PDEs while light red arrows indicate changes in ligand and receptor expression in $\mathrm{HF}$. 5- $\mathrm{HT}_{4}$ receptors are increased in HF and their stimulation induces a PIR and LR. Both GC-B and sGC stimulation increases cGMP that inhibits PDE3 activity towards 5- $\mathrm{HT}_{4}$-stimulated cAMP (light green). 5- $\mathrm{HT}_{4}, 5-\mathrm{HT}_{4}$ serotonin receptor; other abbreviations as in Figure 1. Created with BioRender.com. 
Table 1. Modulation of PDEs in heart failure.

\begin{tabular}{cccccc}
\hline PDE & Expression & Activity & Localization & References \\
\hline PDE2 & $\uparrow$ & $\uparrow$ & $\uparrow$ activity around $\beta_{2}$-AR and PLB $\downarrow$ activity around $\beta_{1}$-AR & {$[134,141,180]$} & {$[141,181-185]$} \\
\hline PDE3 & $\downarrow \uparrow$ & $\downarrow \uparrow$ & $\uparrow$ activity around $\beta_{1}$-AR & [PDE4D activity around RyR & [40,63,76,79,183,186] \\
\hline PDE4 & $\downarrow$ & $\downarrow$ & From Z-line localization to diffuse localization & {$[187-191]$} \\
\hline PDE5 & $\uparrow$ & $\uparrow$ & & & {$[105]$} \\
\hline PDE9 & $\uparrow$ & $\uparrow$ & & & [3] \\
\hline PDE10 & $\uparrow$ & $\uparrow$ & Upregulated for an arrow that points up, and downregulated for the arrow that points down.
\end{tabular}

\subsection{PDE2}

PDE2 expression increases in HF $[134,180]$. However, it is not clear whether activation or inhibition would be beneficial. During HF, the $\beta$-adrenergic pathway is highly activated and can trigger detrimental effects in the heart, hence activating PDE2 would counteract such effects. Accordingly, PDE2 overexpression reduces $\beta$-AR-stimulated LTCC current and prevents the cAMP-mediated inotropic and lusitropic response and hypertrophy [134]. In addition, increase in PDE2 expression prevents arrhythmias and is beneficial after myocardial infarction in mouse models, maintaining cardiac contractility [192]. On the contrary, overexpression of PDE2 showed increased stiffness in connective tissue [193] and this might be due to diminished anti-fibrotic effects of cGMP and cAMP [194,195] or to decreased phosphorylation of titin through PKA or PKG [196]. Inhibition of PDE2 enhancing cAMP/cGMP might be beneficial against cardiac hypertrophy $[170,197,198]$ and might counteract development of HF.

\subsection{PDE3}

In heart failure, alteration in PDE3 expression is not that clear. Some studies show a reduction in both humans and animal models [181-184], whereas other studies in animal models show an increase [185] or no change [98]. These discrepancies could be due to different HF models and different species. Inhibition of PDE3 was previously considered as a potential treatment for heart failure, as it would increase cAMP and ameliorate cardiac contractility and relaxation. Therefore, several PDE3 inhibitors were studied for chronic heart failure treatment (milrinone, amrinone, enoximone, and cilostazol). However, the initial promising results failed in clinical studies showing increased mortality $[199,200]$. Years earlier, a downregulation of $\beta$-ARs was observed in failing hearts, together with higher levels of inhibitory $G$ proteins [201]. It was then postulated that chronic sympathetic stimulation of the heart triggers compensatory mechanisms aiming to reduce energyconsuming mechanisms, resulting in cardiac failure. This explained why treatment with PDE3 inhibitors was deleterious in chronic HF and a break-through in the HF therapy occurred with the successful outcome of using $\beta$-blockers [154,163]. Currently, milrinone is used for acute decompensated heart failure [162,202] and it is found to be well tolerated in patients with HFpEF, but further studies in these patients are required [203]. Since mouse studies knocking down PDE3 show different effects of PDE3A and PDE3B in the heart, this suggests that PDE3A is the more important isoform in regulating contractility [146,204].

\subsection{PDE4}

In HF expression of both PDE4A and PDE4B, as well as PDE4 activity, is reduced and accompanied by heart dysfunction $[40,63,76,79,184,186]$. In support of decreased PDE4 levels, inhibition of PDE4 does not affect $\beta$-AR-mediated contractility in human failing hearts $[52,63,65,66,153,205]$, nor in failing rat ventricles [40], but simultaneously inhibiting PDE3 and PDE4 showed an effect greater than PDE3 inhibition alone in failing human and rat ventricle $[40,52]$ as well as human atrium [63]. 
In a recent study, PDE4B overexpression both decreased contractility and lusitropic responses through reduced phosphorylation of PLB, TnI, and MyBPC [206]. In addition, using several HFrEF models, PDE4B overexpression (either through mild transgenic overexpression or heart-specific AAV9-induced expression) was shown to be cardioprotective [206]. It would therefore be interesting to determine whether cardiac PDE4B overexpression in humans is beneficial in HFrEF.

\subsection{PDE5}

PDE5 activity is enhanced in HF, both in humans and in animal models [166,187,207-209] and its localization is rather diffuse [187-190,210], with a possible functional retargeting to the ANP-stimulated cGMP pool [191]. Long-term treatment with the PDE5 inhibitor tadalafil restored the cardiac response to $\beta$-AR stimulation, improved contractility, and reversed the T-tubule loss typically associated with HF remodeling [211,212]. In humans, long-term PDE5 inhibition has shown beneficial effects in HFrEF but has failed to show clinical benefits in HFpEF [213-217]. However, currently it is still discussed whether PDE5 is expressed in cardiomyocytes, and therefore its function in the myocardium is controversial, as reviewed recently by Dunkerly-Eyring and Kass [218].

\subsection{PDE9}

The expression of PDE9 in the heart is low, but it is upregulated in human left ventricular biopsies from HFpEF and aortic stenosis patients and in animals with HFrEF [105]. Inhibiting or knocking out PDE9 improves ejection fraction and left ventricular diastolic filling in animal models of HF and is protective against hypertrophy and fibrosis $[105,219,220]$.

\section{Orchestration of Cyclic Nucleotide Signaling in Nanodomains}

For many years, studies on the intracellular signaling modulating contractility have focused on measuring global cAMP levels in relation to a specific functional response. However, we now understand more of the organization of the compartmented signaling networks relaying responses, from GPCR activation to cAMP signaling in subcellular nanodomains (recently reviewed by Zaccolo et al. [221]). Consequently, instead of measuring global cyclic nucleotide levels, investigating local changes in cAMP and cGMP is needed in order to understand the mechanisms behind specific downstream effects. This has largely been achieved by the development of FRET-based biosensors, which can measure cAMP and cGMP in real time in living cells, and through targeting these to specific subcellular compartments. Compartmentation can also explain the disparities between which PDE was important for the regulation of global cellular cAMP and cGMP levels, versus which PDE was involved in regulation of cAMP- and cGMP-mediated functional responses. For example, PDE3 is the most sensitive for both cAMP and cGMP. Considering that basal cAMP concentrations are around $1 \mu \mathrm{M}$ and cGMP concentrations around $10 \mathrm{nM}$ [74,106,222], PDE3 in unstimulated conditions would mainly hydrolyze cAMP. Together with PDE3, also PDE4 has been shown to constrain basal cAMP levels. However, the affinity of PDE4 for cAMP is more than 10-fold lower than PDE3 and also above the basal cAMP levels. Moreover, PDE2 has even lower affinity for cAMP and should therefore not regulate basal levels, unless its total capacity is very high and thus relevant also well below the $\mathrm{K}_{\mathrm{m}}$. However, inhibition of PDE2 increased cell shortening at basal conditions [134]. Similar disparities are seen for cGMP-hydrolyzing PDEs. After CNP stimulation, PDE2 inhibition greatly increased global cGMP levels, significantly more than PDE3 or PDE5 inhibition [64], but when using an untargeted cGMP sensor, PDE3 inhibition increased CNP-stimulated cGMP levels to a greater extent than PDE2 inhibition [24]. Targeting this biosensor to TnI or AKAP18 demonstrated that PDE2 and PDE3 similarly regulate cGMP at these nanodomains and similarly regulate CNP-induced LR [24]. These observations would suggest that CGMP is locally concentrated around the target with specific PDEs regulating the local cGMP levels and inhibiting these PDEs would disrupt the compartmentation, causing a global cGMP increase. 
Localization of signaling in subcellular compartments could also explain the discrepancy between global cAMP concentrations at basal conditions, which are around $1 \mu \mathrm{M}$, and PKA affinity for cAMP, which is $100 \mathrm{nM}$ [222-225]. In subcellular compartments, the local cAMP concentrations would be restricted by the activity of PDEs. However, cAMP is known to diffuse at a higher rate than the catalytic rate of PDEs $[226,227]$. Therefore, it is still puzzling how compartments can occur. Additional understanding on how cyclic nucleotides and PDEs are organized in nanodomains, has been provided by in silico modeling approaches. A recent review on modeling approaches for cAMP compartmentation nicely describes the advances that such studies have provided in better understanding the spatial and temporal organization of the cyclic nucleotide systems in cardiomyocytes. Using spatial and stochastic modeling, it became clear that cAMP could not be freely diffusing in the cells [228]. Recently, it was demonstrated that cAMP diffusion is restricted in cells and in addition that PDEs create nanodomains of low cAMP [229]. The limited diffusion was due to immobile cAMP binding sites. Another study demonstrated that cAMP is buffered by biomolecular condensates made up by PKA RI subunits that form liquid-liquid phase separation (LLPS) in the cytosol. These LLPSs are able to maintain the free cAMP levels low, so that few cAMP molecules can reach the local targets [230]. Thus, LLPS buffering and PDEs create nanodomains with low cAMP that can protect PKA from unwanted activation, until receptor stimulation enhances cAMP further to overcome both buffering and PDE capacity and thus activate PKA $[229,230]$.

\section{Summary}

Since PDE inhibitors were first used for treatment of HF, many advances have been made in understanding the role of PDEs in cardiac contractility. However, there are some ongoing challenges to consider. For example, a large number of studies are conducted using animal models where PDE activity and expression can be different from those in humans, and thus caution is needed when interpreting the data. As we appreciate more the importance of signaling compartmentation, localization of specific PDEs is also of relevance in modulation of contractility.

Real-time measurements of cAMP and cGMP using targeted biosensors has been pivotal in understanding how PDEs contribute to mediate contractility at the subcellular level and helped to uncover signaling compartmentation. Yet, there are still some questions and challenges remaining: how do PDEs efficiently degrade cAMP/cGMP to protect protein kinase from unwanted cellular activation? How does stimulation of a specific receptor trigger the activation of certain downstream targets and in some compartments rather than others? Moreover, how are the compartments involving cGMP/cAMP cross-talk organized vs. the single cAMP/cGMP compartments?

Using targeted biosensors combined with in silico modeling will help to understand the compartments in a cell, which modulators are involved, the organization of cAMP/cGMP local nanodomains and their size, and how these are affected in cardiac dysfunction.

Heart failure has been associated with changes in either expression or localization of PDEs. In addition, there is evidence that some PDEs can behave in a redundant manner. How one PDE may compensate for changes in the activity of another PDE during signaling modulation or whether this redundancy changes during HF, remains to be fully elucidated.

Funding: This work was supported by the South-Eastern Norway Regional Health Authority (grant 2019051), the Norwegian Council on Cardiovascular Diseases, The Research Council of Norway (grants 303323 and 303490), The Anders Jahre Foundation for the Promotion of Science, The Family Blix Foundation, and the Simon Fougner Hartmann Family Foundation.

Institutional Review Board Statement: Not applicable.

Informed Consent Statement: Not applicable.

Data Availability Statement: Not applicable. 
Conflicts of Interest: The authors declare no conflict of interest. The funders had no role in the writing of the manuscript, or in the decision to publish.

\section{References}

1. Bender, A.T.; Beavo, J.A. Cyclic Nucleotide Phosphodiesterases: Molecular Regulation to Clinical Use. Pharmacol. Rev. 2006, 58, 488-520. [CrossRef] [PubMed]

2. Kokkonen, K.; Kass, D.A. Nanodomain Regulation of Cardiac Cyclic Nucleotide Signaling by Phosphodiesterases. Annu. Rev. Pharmacol. Toxicol. 2017, 57, 455-479. [CrossRef] [PubMed]

3. Chen, S.; Zhang, Y.; Lighthouse, J.K.; Mickelsen, D.M.; Wu, J.; Yao, P.; Small, E.M.; Yan, C. A Novel Role of Cyclic Nucleotide Phosphodiesterase 10A in Pathological Cardiac Remodeling and Dysfunction. Circulation 2020, 141, 217-233. [CrossRef] [PubMed]

4. Katrukha, I.A. Human cardiac troponin complex. Structure and functions. Biochemistry 2013, 78, 1447-1465. [CrossRef] [PubMed]

5. Bers, D.M. Cardiac excitation-contraction coupling. Nature 2002, 415, 198-205. [CrossRef]

6. Taskén, K.; Aandahl, E.M. Localized Effects of cAMP Mediated by Distinct Routes of Protein Kinase A. Physiol. Rev. 2004, 84, 137-167. [CrossRef]

7. Dodge-Kafka, K.L.; Langeberg, L.; Scott, J.D. Compartmentation of cyclic nucleotide signaling in the heart: The role of A-kinase anchoring proteins. Circ. Res. 2006, 98, 993-1001. [CrossRef]

8. Biel, M.; Michalakis, S. Cyclic nucleotide-gated channels. Handb. Exp. Pharmacol. 2009, 191, 111-136.

9. Schindler, R.F.; Brand, T. The Popeye domain containing protein family-A novel class of cAMP effectors with important functions in multiple tissues. Prog. Biophys. Mol. Biol. 2016, 120, 28-36. [CrossRef]

10. Laudette, M.; Zuo, H.; Lezoualc'H, F.; Schmidt, M. Epac Function and cAMP Scaffolds in the Heart and Lung. J. Cardiovasc. Dev. Dis. 2018, 5, 9. [CrossRef]

11. Ercu, M.; Klussmann, E. Roles of A-Kinase Anchoring Proteins and Phosphodiesterases in the Cardiovascular System. J. Cardiovasc. Dev. Dis. 2018, 5, 14. [CrossRef] [PubMed]

12. Liu, Y.; Chen, J.; Fontes, S.K.; Bautista, E.N.; Cheng, Z. Physiological and pathological roles of protein kinase A in the heart. Cardiovasc. Res. 2021, 118, 386-398. [CrossRef] [PubMed]

13. Potter, L.R. Guanylyl cyclase structure, function and regulation. Cell. Signal. 2011, 23, 1921-1926. [CrossRef]

14. Gauthier, C.; Leblais, V.; Kobzik, L.; Trochu, J.N.; Khandoudi, N.; Bril, A.; Balligand, J.L.; Le Marec, H. The negative inotropic effect of $\beta_{3}$-adrenoceptor stimulation is mediated by activation of a nitric oxide synthase pathway in human ventricle. J. Clin. Investig. 1998, 102, 1377-1384. [CrossRef]

15. Tsai, E.J.; Kass, D.A. Cyclic GMP signaling in cardiovascular pathophysiology and therapeutics. Pharmacol. Ther. 2009, 122, 216-238. [CrossRef] [PubMed]

16. Adler, J.; Kuret, A.; Längst, N.; Lukowski, R. Targets of cGMP/cGKI in Cardiac Myocytes. J. Cardiovasc. Pharmacol. 2020, 75, 494-507. [CrossRef]

17. Brusq, J.-M.; Mayoux, E.; Guigui, L.; Kirilovsky, J. Effects of C-type natriuretic peptide on rat cardiac contractility. J. Cereb. Blood Flow Metab. 1999, 128, 206-212. [CrossRef]

18. Pierkes, M.; Gambaryan, S.; Bokník, P.; Lohmann, S.M.; Schmitz, W.; Potthast, R.; Holtwick, R.; Kuhn, M. Increased effects of C-type natriuretic peptide on cardiac ventricular contractility and relaxation in guanylyl cyclase A-deficient mice. Cardiovasc. Res. 2002, 53, 852-861. [CrossRef]

19. Wollert, K.C.; Yurukova, S.; Kilic, A.; Begrow, F.; Fiedler, B.; Gambaryan, S.; Walter, U.; Lohmann, S.M.; Kuhn, M. Increased effects of C-type natriuretic peptide on contractility and calcium regulation in murine hearts overexpressing cyclic GMP-dependent protein kinase I. Br. J. Pharmacol. 2003, 140, 1227-1236. [CrossRef]

20. Zhang, Q.; Moalem, J.; Tse, J.; Scholz, P.M.; Weiss, H.R. Effects of natriuretic peptides on ventricular myocyte contraction and role of cyclic GMP signaling. Eur. J. Pharmacol. 2005, 510, 209-215. [CrossRef]

21. Su, J.; Scholz, P.M.; Weiss, H.R. Differential Effects of cGMP Produced by Soluble and Particulate Guanylyl Cyclase on Mouse Ventricular Myocytes. Exp. Biol. Med. 2005, 230, 242-250. [CrossRef] [PubMed]

22. Zhang, Q.; Scholz, P.M.; Pilzak, A.; Su, J.; Weiss, H.R. Role of Phospholamban in Cyclic GMP Mediated Signaling in Cardiac Myocytes. Cell. Physiol. Biochem. 2006, 20, 157-166. [CrossRef] [PubMed]

23. Moltzau, L.R.; Aronsen, J.M.; Meier, S.; Nguyen, C.H.T.; Hougen, K.; Ørstavik, Ø.; Sjaastad, I.; Christensen, G.; Skomedal, T.; Osnes, J.-B.; et al. SERCA2 activity is involved in the CNP-mediated functional responses in failing rat myocardium. J. Cereb. Blood Flow Metab. 2013, 170, 366-379. [CrossRef]

24. Manfra, O.; Calamera, G.; Froese, A.; Arunthavarajah, D.; Surdo, N.C.; Meier, S.; Melleby, A.O.; Aasrum, M.; Aronsen, J.M.; Nikolaev, V.O.; et al. CNP regulates cardiac contractility and increases cGMP near both SERCA and TnI: Difference from BNP visualized by targeted cGMP biosensors. Cardiovasc. Res. 2021. [CrossRef] [PubMed]

25. Gisbert, M.P.; Fischmeister, R. Atrial natriuretic factor regulates the calcium current in frog isolated cardiac cells. Circ. Res. 1988, 62, 660-667. [CrossRef]

26. Méry, P.-F.; Lohmann, S.M.; Walter, U.; Fischmeister, R. Ca ${ }^{2+}$ current is regulated by cyclic GMP-dependent protein kinase in mammalian cardiac myocytes. Proc. Natl. Acad. Sci. USA 1991, 88, 1197-1201. [CrossRef]

27. Tohse, N.; Nakaya, H.; Takeda, Y.; Kanno, M. Cyclic GMP-mediated inhibition of L-type Ca ${ }^{2+}$ channel activity by human natriuretic peptide in rabbit heart cells. Br. J. Pharmacol. 1995, 114, 1076-1082. [CrossRef] 
28. Sodi, R.; Dubuis, E.; Shenkin, A.; Hart, G. B-type natriuretic peptide (BNP) attenuates the L-type calcium current and regulates ventricular myocyte function. Regul. Pept. 2008, 151, 95-105. [CrossRef]

29. Moltzau, L.R.; Aronsen, J.M.; Meier, S.; Skogestad, J.; Ørstavik, Ø.; Lothe, G.B.; Sjaastad, I.; Skomedal, T.; Osnes, J.-B.; Levy, F.O.; et al. Different Compartmentation of Responses to Brain Natriuretic Peptide and C-Type Natriuretic Peptide in Failing Rat Ventricle. J. Pharmacol. Exp. Ther. 2014, 350, 681-690. [CrossRef]

30. Suko, J.; Maurer-Fogy, I.; Plank, B.; Bertel, O.; Wyskovsky, W.; Hohenegger, M.; Hellmann, G. Phosphorylation of serine 2843 in ryanodine receptor-calcium release channel of skeletal muscle by cAMP-, cGMP- and CaM-dependent protein kinase. Biochim. Biophys. Acta 1993, 1175, 193-206. [CrossRef]

31. Xiao, B.; Zhong, G.; Obayashi, M.; Yang, D.; Chen, K.; Walsh, M.P.; Shimoni, Y.; Cheng, H.; Ter Keurs, H.; Chen, S.R.W. Ser-2030, but not Ser-2808, is the major phosphorylation site in cardiac ryanodine receptors responding to protein kinase A activation upon $\beta$-adrenergic stimulation in normal and failing hearts. Biochem. J. 2006, 396, 7-16. [CrossRef] [PubMed]

32. Kaumann, A.J.; Birnbaumer, L. Prostaglandin $\mathrm{E}_{1}$ action on sinus pacemaker and adenylyl cyclase in kitten myocardium. Nature 1974, 251, 515-517. [CrossRef] [PubMed]

33. Hayes, J.S.; Brunton, L.L.; Mayer, S.E. Selective activation of particulate cAMP-dependent protein kinase by isoproterenol and prostaglandin $\mathrm{E}_{1}$. J. Biol. Chem. 1980, 255, 5113-5119. [CrossRef]

34. Hayes, J.; Bowling, N.; King, K.; Boder, G. Evidence for selective regulation of the phosphorylation of myocyte proteins by isoproterenol and prostaglandin $\mathrm{E}_{1}$. Biochim. Biophys. Acta 1982, 714, 136-142. [CrossRef]

35. Buxton, I.L.; Brunton, L.L. Compartments of cyclic AMP and protein kinase in mammalian cardiomyocytes. J. Biol. Chem. 1983, 258, 10233-10239. [CrossRef]

36. Aass, H.; Skomedal, T.; Osnes, J. Increase of cyclic AMP in subcellular fractions of rat heart muscle after $\beta$-adrenergic stimulation: Prenalterol and isoprenaline caused different distribution of bound cyclic AMP. J. Mol. Cell. Cardiol. 1988, 20, 847-860. [CrossRef]

37. Defer, N.; Best-Belpomme, M.; Hanoune, J. Tissue specificity and physiological relevance of various isoforms of adenylyl cyclase. Am. J. Physiol. Physiol. 2000, 279, F400-F416. [CrossRef]

38. Steinberg, S.F. The Molecular Basis for Distinct $\beta$-Adrenergic Receptor Subtype Actions in Cardiomyocytes. Circ. Res. 1999, 85, 1101-1111. [CrossRef]

39. Xiao, R.P. $\beta$-adrenergic signaling in the heart: Dual coupling of the $\beta_{2}$-adrenergic receptor to $G_{\mathrm{s}}$ and $G_{i}$ proteins. Sci. STKE 2001, 2001, re15. [CrossRef]

40. Afzal, F.; Aronsen, J.M.; Moltzau, L.R.; Sjaastad, I.; Levy, F.O.; Skomedal, T.; Osnes, J.B.; Qvigstad, E. Differential regulation of $\beta_{2}$ -adrenoceptor-mediated inotropic and lusitropic response by PDE3 and PDE4 in failing and non-failing rat cardiac ventricle. Br. J. Pharmacol. 2011, 162, 54-71. [CrossRef]

41. Chen-Izu, Y.; Xiao, R.-P.; Izu, L.T.; Cheng, H.; Kuschel, M.; Spurgeon, H.; Lakatta, E.G. Gi-Dependent Localization of $\beta_{2}$-Adrenergic Receptor Signaling to L-Type Ca ${ }^{2+}$ Channels. Biophys. J. 2000, 79, 2547-2556. [CrossRef]

42. Xiao, R.P.; Ji, X.; Lakatta, E.G. Functional coupling of the $\beta 2$-adrenoceptor to a pertussis toxin-sensitive $G$ protein in cardiac myocytes. Mol. Pharmacol. 1995, 47, 322-329. [PubMed]

43. Xiao, R.P.; Avdonin, P.; Zhou, Y.Y.; Cheng, H.; Akhter, S.A.; Eschenhagen, T.; Lefkowitz, R.J.; Koch, W.J.; Lakatta, E.G. Coupling of $\beta_{2}$-adrenoceptor to Gi proteins and its physiological relevance in murine cardiac myocytes. Circ. Res. 1999, 84, 43-52. [CrossRef]

44. Kuschel, M.; Zhou, Y.Y.; Cheng, H.; Zhang, S.J.; Chen, Y.; Lakatta, E.G.; Xiao, R.P. Gi protein-mediated functional compartmentalization of cardiac $\beta_{2}$-adrenergic signaling. J. Biol. Chem. 1999, 274, 22048-22052. [CrossRef] [PubMed]

45. Nikolaev, V.O.; Bünemann, M.; Schmitteckert, E.; Lohse, M.J.; Engelhardt, S. Cyclic AMP imaging in adult cardiac myocytes reveals far-reaching $\beta_{1}$-adrenergic but locally confined $\beta_{2}$-adrenergic receptor-mediated signaling. Circ. Res. 2006, 99, 1084-1091. [CrossRef]

46. Nikolaev, V.O.; Moshkov, A.; Lyon, A.R.; Miragoli, M.; Novak, P.; Paur, H.; Lohse, M.J.; Korchev, Y.E.; Harding, S.E.; Gorelik, J. $\beta_{2}$-Adrenergic Receptor Redistribution in Heart Failure Changes cAMP Compartmentation. Science 2010, 327, 1653-1657. [CrossRef]

47. MacDougall, D.A.; Agarwal, S.R.; Stopford, E.A.; Chu, H.; Collins, J.A.; Longster, A.L.; Colyer, J.; Harvey, R.D.; Calaghan, S. Caveolae compartmentalise $\beta_{2}$-adrenoceptor signals by curtailing cAMP production and maintaining phosphatase activity in the sarcoplasmic reticulum of the adult ventricular myocyte. J. Mol. Cell. Cardiol. 2012, 52, 388-400. [CrossRef]

48. Wright, P.T.; Nikolaev, V.O.; O’hara, T.; Diakonov, I.; Bhargava, A.; Tokar, S.; Schobesberger, S.; Shevchuk, A.I.; Sikkel, M.B.; Wilkinson, R.; et al. Caveolin-3 regulates compartmentation of cardiomyocyte $\beta_{2}$-adrenergic receptor-mediated cAMP signaling. J. Mol. Cell. Cardiol. 2014, 67, 38-48. [CrossRef]

49. Brattelid, T.; Qvigstad, E.; Lynham, J.A.; Molenaar, P.; Aass, H.; Geiran, O.; Skomedal, T.; Levy, F.O.; Kaumann, A.J. Functional serotonin 5- $\mathrm{HT}_{4}$ receptors in porcine and human ventricular myocardium with increased 5-HT4 mRNA in heart failure. NaunynSchmiedebergs Arch. Exp. Pathol. Pharmakol. 2004, 370, 157-166. [CrossRef]

50. Qvigstad, E.; Brattelid, T.; Sjaastad, I.; Andressen, K.W.; Krobert, K.A.; Birkeland, J.A.; Sejersted, O.M.; Kaumann, A.J.; Skomedal, T.; Osnes, J.-B.; et al. Appearance of a ventricular 5-HT receptor-mediated inotropic response to serotonin in heart failure. Cardiovasc. Res. 2005, 65, 869-878. [CrossRef]

51. Kaumann, A.J.; Levy, F.O. 5-Hydroxytryptamine receptors in the human cardiovascular system. Pharmacol. Ther. 2006, 111, 674-706. [CrossRef] [PubMed] 
52. Afzal, F.; Andressen, K.W.; Mørk, H.K.; Aronsen, J.M.; Sjaastad, I.; Dahl, C.P.; Skomedal, T.; Levy, F.O.; Osnes, J.B.; Qvigstad, E. 5- $\mathrm{HT}_{4}$-elicited positive inotropic response is mediated by cAMP and regulated by PDE3 in failing rat and human cardiac ventricles. Br. J. Pharmacol. 2008, 155, 1005-1014. [CrossRef] [PubMed]

53. Afzal, F.; Qvigstad, E.; Aronsen, J.M.; Moltzau, L.R.; Sjaastad, I.; Skomedal, T.; Osnes, J.-B.; Levy, F.O. Agents increasing cyclic GMP amplify 5 - $\mathrm{HT}_{4}$-elicited positive inotropic response in failing rat cardiac ventricle. Naunyn Schmiedebergs Arch. Exp. Pathol. Pharmakol. 2011, 384, 543-553. [CrossRef] [PubMed]

54. Kostic, M.; Erdogan, S.; Rena, G.; Borchert, G.; Hoch, B.; Bartel, S.; Scotland, G.; Huston, E.; Houslay, M.; Krause, E.-G. Altered Expression of PDE1 and PDE4 Cyclic Nucleotide Phosphodiesterase Isoforms in 7-oxo-prostacyclin-preconditioned Rat Heart. J. Mol. Cell. Cardiol. 1997, 29, 3135-3146. [CrossRef] [PubMed]

55. Hoffmann, R.; Baillie, G.S.; MacKenzie, S.J.; Yarwood, S.J.; Houslay, M.D. The MAP kinase ERK2 inhibits the cyclic AMP-specific phosphodiesterase HSPDE4D3 by phosphorylating it at Ser579. EMBO J. 1999, 18, 893-903. [CrossRef] [PubMed]

56. Sette, C.; Conti, M. Phosphorylation and activation of a cAMP-specific phosphodiesterase by the cAMP-dependent protein kinase. Involvement of serine 54 in the enzyme activation. J. Biol. Chem. 1996, 271, 16526-16534. [CrossRef]

57. MacKenzie, S.J.; Baillie, G.; McPhee, I.; MacKenzie, C.; Seamons, R.; McSorley, T.; Millen, J.; Beard, M.B.; Van Heeke, G.; Houslay, M.D. Long PDE4 cAMP specific phosphodiesterases are activated by protein kinase A-mediated phosphorylation of a single serine residue in Upstream Conserved Region 1 (UCR1). J. Cereb. Blood Flow Metab. 2002, 136, 421-433. [CrossRef]

58. Houslay, M.D.; Adams, D.R. PDE4 cAMP phosphodiesterases: Modular enzymes that orchestrate signalling cross-talk, desensitization and compartmentalization. Biochem. J. 2003, 370, 1-18. [CrossRef]

59. Huston, E.; Gall, I.; Houslay, T.M.; Houslay, M.D. Helix-1 of the cAMP-specific phosphodiesterase PDE4A1 regulates its phospholipase-D-dependent redistribution in response to release of $\mathrm{Ca}^{2+}$. J. Cell Sci. 2006, 119, 3799-3810. [CrossRef]

60. Wills, L.; Ehsan, M.; Whiteley, E.L.; Baillie, G.S. Location, location, location: PDE4D5 function is directed by its unique N-terminal region. Cell. Signal. 2016, 28, 701-705. [CrossRef]

61. Richter, W.; Xie, M.; Scheitrum, C.; Krall, J.; Movsesian, M.A.; Conti, M. Conserved expression and functions of PDE4 in rodent and human heart. Basic Res. Cardiol. 2010, 106, 249-262. [CrossRef] [PubMed]

62. Qvigstad, E.; Moltzau, L.R.; Aronsen, J.M.; Nguyen, C.H.; Hougen, K.; Sjaastad, I.; Levy, F.O.; Skomedal, T.; Osnes, J.-B. Natriuretic peptides increase $\beta_{1}$-adrenoceptor signalling in failing hearts through phosphodiesterase 3 inhibition. Cardiovasc. Res. 2009, 85, 763-772. [CrossRef] [PubMed]

63. Molina, C.E.; Leroy, J.; Richter, W.; Xie, M.; Scheitrum, C.; Lee, I.O.; Maack, C.; Rucker-Martin, C.; Donzeau-Gouge, P.; Verde, I.; et al. Cyclic adenosine monophosphate phosphodiesterase type 4 protects against atrial arrhythmias. J. Am. Coll. Cardiol. 2012, 59, 2182-2190. [CrossRef]

64. Moltzau, L.R.; Meier, S.; Aronsen, J.M.; Afzal, F.; Sjaastad, I.; Skomedal, T.; Osnes, J.-B.; Levy, F.O.; Qvigstad, E. Differential regulation of C-type natriuretic peptide-induced cGMP and functional responses by PDE2 and PDE3 in failing myocardium. Naunyn Schmiedebergs Arch. Exp. Pathol. Pharmakol. 2014, 387, 407-417. [CrossRef] [PubMed]

65. Molenaar, P.; Christ, T.; Hussain, R.I.; Engel, A.; Berk, E.; Gillette, K.T.; Chen, L.; Galindo-Tovar, A.; Krobert, K.A.; Ravens, U.; et al. PDE3, but not PDE4, reduces $\beta_{1}$ - and $\beta_{2}$-adrenoceptor-mediated inotropic and lusitropic effects in failing ventricle from metoprolol-treated patients. Br. J. Pharmacol. 2013, 169, 528-538. [CrossRef]

66. Molenaar, P.; Christ, T.; Berk, E.; Engel, A.; Gillette, K.T.; Galindo-Tovar, A.; Ravens, U.; Kaumann, A.J. Carvedilol induces greater control of $\beta_{2}$ - than $\beta_{1}$-adrenoceptor-mediated inotropic and lusitropic effects by PDE3, while PDE4 has no effect in human failing myocardium. Naunyn Schmiedebergs Arch. Pharmacol. 2014, 387, 629-640. [CrossRef]

67. Verde, I.; Vandecasteele, G.; Lezoualc'H, F.; Fischmeister, R. Characterization of the cyclic nucleotide phosphodiesterase subtypes involved in the regulation of the L-type $\mathrm{Ca}^{2+}$ current in rat ventricular myocytes. J. Cereb. Blood Flow Metab. 1999, 127, 65-74. [CrossRef]

68. Mongillo, M.; McSorley, T.; Evellin, S.; Sood, A.; Lissandron, V.; Terrin, A.; Huston, E.; Hannawacker, A.; Lohse, M.J.; Pozzan, T.; et al. Fluorescence Resonance Energy Transfer-Based Analysis of cAMP Dynamics in Live Neonatal Rat Cardiac Myocytes Reveals Distinct Functions of Compartmentalized Phosphodiesterases. Circ. Res. 2004, 95, 67-75. [CrossRef]

69. Mika, D.; Bobin, P.; Lindner, M.; Boet, A.; Hodzic, A.; Lefebvre, F.; Lechène, P.; Sadoune, M.; Samuel, J.-L.; Algalarrondo, V.; et al. Synergic PDE3 and PDE4 control intracellular cAMP and cardiac excitation-contraction coupling in a porcine model. J. Mol. Cell. Cardiol. 2019, 133, 57-66. [CrossRef]

70. Cosson, M.-V.; Hiis, H.G.; Moltzau, L.R.; Levy, F.O.; Krobert, K.A. Knockout of adenylyl cyclase isoform 5 or 6 differentially modifies the $\beta_{1}$-adrenoceptor-mediated inotropic response. J. Mol. Cell. Cardiol. 2019, 131, 132-145. [CrossRef]

71. Vargas, M.L.; Hernandez, J.; Kaumann, A.J. Phosphodiesterase PDE3 blunts the positive inotropic and cyclic AMP enhancing effects of CGP12177 but not of noradrenaline in rat ventricle. Br. J. Pharmacol. 2006, 147, 158-163. [CrossRef]

72. Galindo-Tovar, A.; Kaumann, A.J. Phosphodiesterase-4 blunts inotropism and arrhythmias but not sinoatrial tachycardia of (-)-adrenaline mediated through mouse cardiac $\beta_{1}$-adrenoceptors. J. Cereb. Blood Flow Metab. 2008, 153, 710-720. [CrossRef] [PubMed]

73. Wright, P.T.; Bhogal, N.K.; Diakonov, I.; Pannell, L.M.K.; Perera, R.K.; Bork, N.I.; Schobesberger, S.; Lucarelli, C.; Faggian, G.; Alvarez-Laviada, A.; et al. Cardiomyocyte membrane structure and cAMP compartmentation produce anatomical variation in $\beta_{2}$ AR-cAMP responsiveness in murine hearts. Cell Rep. 2018, 23, 459-469. [CrossRef] [PubMed] 
74. Sprenger, J.U.; Perera, R.K.; Steinbrecher, J.H.; Lehnart, S.E.; Maier, L.S.; Hasenfuss, G.; Nikolaev, V. In vivo model with targeted cAMP biosensor reveals changes in receptor-microdomain communication in cardiac disease. Nat. Commun. 2015, 6, 6965. [CrossRef]

75. Rudokas, M.W.; Post, J.P.; Sataray-Rodriguez, A.; Sherpa, R.T.; Moshal, K.S.; Agarwal, S.R.; Harvey, R.D. Compartmentation of $\beta_{2}$-adrenoceptor stimulated cAMP responses by phosphodiesterase types 2 and 3 in cardiac ventricular myocytes. Br. J. Pharmacol. 2021, 178, 1574-1587. [CrossRef] [PubMed]

76. Lehnart, S.E.; Wehrens, X.H.T.; Reiken, S.; Warrier, S.; Belevych, A.E.; Harvey, R.D.; Richter, W.; Jin, S.-L.C.; Conti, M.; Marks, A.R. Phosphodiesterase 4D Deficiency in the Ryanodine-Receptor Complex Promotes Heart Failure and Arrhythmias. Cell 2005, 123, 25-35. [CrossRef]

77. Beca, S.; Helli, P.B.; Simpson, J.A.; Zhao, D.; Farman, G.P.; Jones, P.; Tian, X.; Wilson, L.S.; Ahmad, F.; Chen, S.R.W.; et al. Phosphodiesterase $4 \mathrm{D}$ regulates baseline sarcoplasmic reticulum $\mathrm{Ca}^{2+}$ release and cardiac contractility, independently of L-type $\mathrm{Ca}^{2+}$ current. Circ. Res. 2011, 109, 1024-1030. [CrossRef]

78. Bünemann, M.; Gerhardstein, B.L.; Gao, T.; Hosey, M.M. Functional Regulation of L-type Calcium Channels via Protein Kinase A-mediated Phosphorylation of the $\beta_{2}$ Subunit. J. Biol. Chem. 1999, 274, 33851-33854. [CrossRef]

79. Leroy, J.; Richter, W.; Mika, D.; Castro, L.R.; Abi-Gerges, A.; Xie, M.; Scheitrum, C.; Lefebvre, F.; Schittl, J.; Mateo, P.; et al Phosphodiesterase 4B in the cardiac L-type $\mathrm{Ca}^{2+}$ channel complex regulates $\mathrm{Ca}^{2+}$ current and protects against ventricular arrhythmias in mice. J. Clin. Investig. 2011, 121, 2651-2661. [CrossRef]

80. Berisha, F.; Götz, K.R.; Wegener, J.W.; Brandenburg, S.; Subramanian, H.; Molina, C.E.; Ruffer, A.; Petersen, J.; Bernhardt, A.; Girdauskas, E.; et al. cAMP imaging at ryanodine receptors reveals $\beta_{2}$-adrenoceptor driven arrhythmias. Circ. Res. 2021, 129, 81-94. [CrossRef]

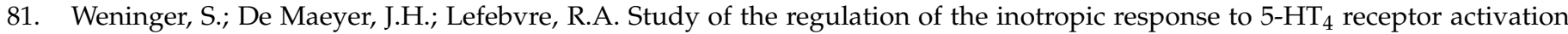
via phosphodiesterases and its cross-talk with C-type natriuretic peptide in porcine left atrium. Naunyn-Schmiedeberg's Arch. Pharmacol. 2012, 385, 565-577. [CrossRef] [PubMed]

82. Melsom, C.B.; Hussain, R.I.; Ørstavik, Ø.; Aronsen, J.M.; Sjaastad, I.; Skomedal, T.; Osnes, J.-B.; Levy, F.O.; Krobert, K.A Non-classical regulation of $\beta_{1}$ - and $\beta_{2}$-adrenoceptor-mediated inotropic responses in rat heart ventricle by the $G$ protein $G_{i}$. Naunyn Schmiedebergs Arch. Exp. Pathol. Pharmakol. 2014, 387, 1177-1186. [CrossRef] [PubMed]

83. Melsom, C.B.; Ørstavik, Ø.; Osnes, J.B.; Skomedal, T.; Levy, F.O.; Krobert, K.A. Gi proteins regulate adenylyl cyclase activity independent of receptor activation. PLoS ONE 2014, 9, e106608. [CrossRef]

84. Abi-Gerges, A.; Castro, L.; Leroy, J.; Domergue, V.; Fischmeister, R.; Vandecasteele, G. Selective changes in cytosolic $\beta$-adrenergic cAMP signals and L-type Calcium Channel regulation by Phosphodiesterases during cardiac hypertrophy. J. Mol. Cell. Cardiol. 2020, 150, 109-121. [CrossRef] [PubMed]

85. Weninger, S.; De Maeyer, J.H.; Lefebvre, R.A. Influence of phosphodiesterases and cGMP on cAMP generation and on phosphorylation of phospholamban and troponin I by $5-\mathrm{HT}_{4}$ receptor activation in porcine left atrium. Naunyn-Schmiedebergs Arch. Exp. Pathol. Pharmakol. 2013, 386, 671-684. [CrossRef] [PubMed]

86. Dolce, B.; Christ, T.; Pavlidou, N.G.; Yildirim, Y.; Reichenspurner, H.; Eschenhagen, T.; Nikolaev, V.O.; Kaumann, A.J.; Molina, C.E. Impact of phosphodiesterases PDE3 and PDE4 on 5-hydroxytryptamine receptor4-mediated increase of cAMP in human atrial fibrillation. Naunyn Schmiedebergs Arch. Exp. Pathol. Pharmakol. 2020, 394, 291-298. [CrossRef]

87. Zhao, C.Y.; Greenstein, J.L.; Winslow, R.L. Interaction between phosphodiesterases in the regulation of the cardiac $\beta$-adrenergic pathway. J. Mol. Cell. Cardiol. 2015, 88, 29-38. [CrossRef]

88. Soderling, S.H.; Bayuga, S.J.; Beavo, J.A. Cloning and characterization of a cAMP-specific cyclic nucleotide phosphodiesterase Proc. Natl. Acad. Sci. USA 1998, 95, 8991-8996. [CrossRef]

89. Galperin, M.Y.; Nikolskaya, A.N.; Koonin, E.V. Novel domains of the prokaryotic two-component signal transduction systems. FEMS Microbiol. Lett. 2001, 203, 11-21. [CrossRef]

90. Gilles-Gonzalez, M.-A.; Gonzalez, G.; Sieck, G.C. Signal transduction by heme-containing PAS-domain proteins. J. Appl. Physiol. 2004, 96, 774-783. [CrossRef]

91. Patrucco, E.; Albergine, M.S.; Santana, L.; Beavo, J.A. Phosphodiesterase 8A (PDE8A) regulates excitation-contraction coupling in ventricular myocytes. J. Mol. Cell. Cardiol. 2010, 49, 330-333. [CrossRef] [PubMed]

92. Mery, P.F.; Pavoine, C.; Belhassen, L.; Pecker, F.; Fischmeister, R. Nitric oxide regulates cardiac Ca ${ }^{2+}$ current. Involvement of cGMP-inhibited and cGMP-stimulated phosphodiesterases through guanylyl cyclase activation. J. Biol. Chem. 1993, 268, 26286-26295. [CrossRef]

93. Weyrich, A.; Ma, X.L.; Buerke, M.; Murohara, T.; Armstead, V.E.; Lefer, A.M.; Nicolas, J.M.; Thomas, A.; Lefer, D.J.; VintenJohansen, J. Physiological concentrations of nitric oxide do not elicit an acute negative inotropic effect in unstimulated cardiac muscle. Circ. Res. 1994, 75, 692-700. [CrossRef] [PubMed]

94. Nawrath, H.; Bäumner, D.; Rupp, J.; Oelert, H. The ineffectiveness of the NO-cyclic GMP signaling pathway in the atrial myocardium. J. Cereb. Blood Flow Metab. 1995, 116, 3061-3067. [CrossRef]

95. Kojda, G.; Kottenberg, K.; Nix, P.; Schlüter, K.D.; Piper, H.M.; Noack, E. Low Increase in cGMP Induced by Organic Nitrates and Nitrovasodilators Improves Contractile Response of Rat Ventricular Myocytes. Circ. Res. 1996, 78, 91-101. [CrossRef] [PubMed]

96. Flesch, M.; Kilter, H.; Cremers, B.; Lenz, O.; Südkamp, M.; Kuhn-Regnier, F.; Böhm, M. Acute effects of nitric oxide and cyclic GMP on human myocardial contractility. J. Pharmacol. Exp. Ther. 1997, 281, 1340-1349. 
97. Takimoto, E.; Belardi, D.; Tocchetti, C.G.; Vahebi, S.; Cormaci, G.; Ketner, E.A.; Moens, A.L.; Champion, H.C.; Kass, D.A. Compartmentalization of Cardiac $\beta$-Adrenergic Inotropy Modulation by Phosphodiesterase Type 5. Circulation 2007, 115, 2159-2167. [CrossRef]

98. Meier, S.; Andressen, K.W.; Aronsen, J.M.; Sjaastad, I.; Hougen, K.; Skomedal, T.; Osnes, J.B.; Qvigstad, E.; Levy, F.O.; Moltzau, L.R. PDE3 inhibition by C-type natriuretic peptide-induced cGMP enhances cAMP-mediated signaling in both non-failing and failing hearts. Eur. J. Pharmacol. 2017, 812, 174-183. [CrossRef]

99. Tajima, M.; Bartunek, J.; Weinberg, E.; Ito, N.; Lorell, B.H. Atrial Natriuretic Peptide Has Different Effects on Contractility and Intracellular pH in Normal and Hypertrophied Myocytes from Pressure-Overloaded Hearts. Circulation 1998, 98, $2760-2764$. [CrossRef]

100. Frantz, S.; Klaiber, M.; Baba, H.A.; Oberwinkler, H.; Völker, K.; Gaßner, B.; Bayer, B.; Abeßer, M.; Schuh, K.; Feil, R.; et al. Stress-dependent dilated cardiomyopathy in mice with cardiomyocyte-restricted inactivation of cyclic GMP-dependent protein kinase I. Eur. Heart, J. 2011, 34, 1233-1244. [CrossRef]

101. Lin, C.S.; Lau, A.; Tu, R.; Lue, T.F. Expression of three isoforms of cGMP-binding cGMP-specific phosphodiesterase (PDE5) in human penile cavernosum. Biochem. Biophys. Res. Commun. 2000, 268, 628-635. [CrossRef] [PubMed]

102. Castro, L.R.; Schittl, J.; Fischmeister, R. Feedback control through cGMP-dependent protein kinase contributes to differential regulation and compartmentation of cGMP in rat cardiac myocytes. Circ. Res. 2010, 107, 1232-1240. [CrossRef] [PubMed]

103. Takimoto, E.; Champion, H.C.; Belardi, D.; Moslehi, J.; Mongillo, M.; Mergia, E.; Montrose, D.C.; Isoda, T.; Aufiero, K.; Zaccolo, M.; et al. cGMP Catabolism by Phosphodiesterase 5A Regulates Cardiac Adrenergic Stimulation by NOS3-Dependent Mechanism. Circ. Res. 2005, 96, 100-109. [CrossRef] [PubMed]

104. Castro, L.R.V.; Verde, I.; Cooper, D.M.; Fischmeister, R. Cyclic Guanosine Monophosphate Compartmentation in Rat Cardiac Myocytes. Circulation 2006, 113, 2221-2228. [CrossRef]

105. Lee, D.I.; Zhu, G.; Sasaki, T.; Cho, G.-S.; Hamdani, N.; Holewinski, R.J.; Jo, S.-H.; Danner, T.; Zhang, M.; Rainer, P.P.; et al. Phosphodiesterase 9A controls nitric-oxide-independent cGMP and hypertrophic heart disease. Nature 2015, 519, 472-476. [CrossRef]

106. Götz, K.R.; Sprenger, J.U.; Perera, R.K.; Steinbrecher, J.H.; Lehnart, S.E.; Kuhn, M.; Gorelik, J.; Balligand, J.-L.; Nikolaev, V.O. Transgenic Mice for Real-Time Visualization of cGMP in Intact Adult Cardiomyocytes. Circ. Res. 2014, 114, 1235-1245. [CrossRef]

107. Borlaug, B.A.; Melenovsky, V.; Marhin, T.; Fitzgerald, P.; Kass, D.A. Sildenafil Inhibits $\beta$-Adrenergic-Stimulated Cardiac Contractility in Humans. Circulation 2005, 112, 2642-2649. [CrossRef]

108. Isidori, A.M.; Cornacchione, M.; Barbagallo, F.; Di Grazia, A.; Barrios, F.; Fassina, L.; Monaco, L.; Giannetta, E.; Gianfrilli, D.; Garofalo, S.; et al. Inhibition of type 5 phosphodiesterase counteracts $\beta 2$-adrenergic signalling in beating cardiomyocytes. Cardiovasc. Res. 2015, 106, 408-420. [CrossRef]

109. Schobesberger, S.; Wright, P.T.; Poulet, C.; Sanchez Alonso Mardones, J.L.; Mansfield, C.; Friebe, A.; Harding, S.E.; Balligand, J.L.; Nikolaev, V.O.; Gorelik, J. $\beta_{3}$-Adrenoceptor redistribution impairs NO/cGMP/PDE2 signalling in failing cardiomyocytes. Elife 2020, 9, e52221. [CrossRef]

110. Mongillo, M.; Tocchetti, C.G.; Terrin, A.; Lissandron, V.; Cheung, Y.F.; Dostmann, W.R.; Pozzan, T.; Kass, D.A.; Paolocci, N.; Houslay, M.D.; et al. Compartmentalized phosphodiesterase-2 activity blunts $\beta$-adrenergic cardiac inotropy via an NO/cGMPdependent pathway. Circ. Res. 2006, 98, 226-234. [CrossRef]

111. Mishra, S.; Sadagopan, N.; Dunkerly-Eyring, B.; Rodriguez, S.; Sarver, D.C.; Ceddia, R.P.; Murphy, S.A.; Knutsdottir, H.; Jani, V.P.; Ashok, D.; et al. Inhibition of phosphodiesterase type 9 reduces obesity and cardiometabolic syndrome in mice. J. Clin. Investig. 2021, 131. [CrossRef] [PubMed]

112. Snyder, P.B.; Florio, V.A.; Ferguson, K.; Loughney, K. Isolation, expression and analysis of splice variants of a human $\mathrm{Ca}^{2+}$ /calmodulin-stimulated phosphodiesterase (PDE1A). Cell. Signal. 1999, 11, 535-544. [CrossRef]

113. Sonnenburg, W.K.; Seger, D.; Kwak, K.S.; Huang, J.; Charbonneau, H.; Beavo, J.A. Identification of inhibitory and calmodulinbinding domains of the PDE1A1 and PDE1A2 calmodulin-stimulated cyclic nucleotide phosphodiesterases. J. Biol. Chem. 1995, 270, 30989-31000. [CrossRef] [PubMed]

114. Sharma, R.K. Diversity of calcium action in regulation of mammalian calmodulin-dependent cyclic nucleotide phosphodiesterase. Indian J. Biochem. Biophys. 2003, 40, 77-91. [PubMed]

115. Geremia, R.; Rossi, P.; Mocini, D.; Pezzotti, R.; Conti, M. Characterization of a calmodulin-dependent high-affinity cyclic AMP and cyclic GMP phosphodiesterase from male mouse germ cells. Biochem. J. 1984, 217, 693-700. [CrossRef] [PubMed]

116. Florio, V.A.; Sonnenburg, W.K.; Johnson, R.; Kwak, K.S.; Jensen, G.S.; Walsh, K.A.; Beavo, J.A. Phosphorylation of the 61-kDa Calmodulin-Stimulated Cyclic Nucleotide Phosphodiesterase at Serine 120 Reduces Its Affinity for Calmodulin. Biochemistry 1994, 33, 8948-8954. [CrossRef]

117. Vandeput, F.; Wolda, S.L.; Krall, J.; Hambleton, R.; Uher, L.; McCaw, K.N.; Radwanski, P.B.; Florio, V.; Movsesian, M.A. Cyclic Nucleotide Phosphodiesterase PDE1C1 in Human Cardiac Myocytes. J. Biol. Chem. 2007, 282, 32749-32757. [CrossRef]

118. Miller, C.L.; Oikawa, M.; Cai, Y.; Wojtovich, A.P.; Nagel, D.J.; Xu, X.; Xu, H.; Florio, V.; Rybalkin, S.D.; Beavo, J.A.; et al. Role of $\mathrm{Ca}^{2+} /$ calmodulin-stimulated cyclic nucleotide phosphodiesterase 1 in mediating cardiomyocyte hypertrophy. Circ. Res. 2009, 105, 956-964. [CrossRef]

119. Hashimoto, T.; Kim, G.E.; Tunin, R.S.; Adesiyun, T.; Hsu, S.; Nakagawa, R.; Zhu, G.; O’Brien, J.J.; Hendrick, J.P.; Davis, R.E.; et al. Acute enhancement of cardiac function by phosphodiesterase type 1 inhibition. Circulation 2018, 138, 1974-1987. [CrossRef] 
120. Knight, W.E.; Chen, S.; Zhang, Y.; Oikawa, M.; Wu, M.; Zhou, Q.; Miller, C.L.; Cai, Y.; Mickelsen, D.M.; Moravec, C.; et al. PDE1C deficiency antagonizes pathological cardiac remodeling and dysfunction. Proc. Natl. Acad. Sci. USA 2016, 113, E7116-E7125. [CrossRef]

121. Muller, G.K.; Song, J.; Jani, V.; Wu, Y.; Liu, T.; Jeffreys, W.P.; O’Rourke, B.; Anderson, M.E.; Kass, D.A. PDE1 Inhibition Modulates $\mathrm{Ca}_{\mathrm{v}}$ 1.2 Channel to Stimulate Cardiomyocyte Contraction. Circ. Res. 2021, 129, 872-886. [CrossRef] [PubMed]

122. Martins, T.J.; Mumby, M.C.; Beavo, J.A. Purification and characterization of a cyclic GMP-stimulated cyclic nucleotide phosphodiesterase from bovine tissues. J. Biol. Chem. 1982, 257, 1973-1979. [CrossRef]

123. Rosman, G.J.; Martins, T.J.; Sonnenburg, W.K.; Beavo, J.A.; Ferguson, K.; Loughney, K. Isolation and characterization of human cDNAs encoding a cGMP-stimulated 3',5'-cyclic nucleotide phosphodiesterase. Gene 1997, 191, 89-95. [CrossRef]

124. Weishaar, R.E.; Burrows, S.D.; Kobylarz, D.C.; Quade, M.M.; Evans, D.B. Multiple molecular forms of cyclic nucleotide phosphodiesterase in cardiac and smooth muscle and in platelets: Isolation, characterization, and effects of various reference phosphodiesterase inhibitors and cardiotonic agents. Biochem. Pharmacol. 1986, 35, 787-800. [CrossRef]

125. Pyne, N.; Cooper, M.E.; Houslay, M. Identification and characterization of both the cytosolic and particulate forms of cyclic GMP-stimulated cyclic AMP phosphodiesterase from rat liver. Biochem. J. 1986, 234, 325-334. [CrossRef]

126. Russwurm, C.; Zoidl, G.; Koesling, D.; Russwurm, M. Dual Acylation of PDE2A Splice Variant 3: Targeting to Synaptic Membranes. J. Biol. Chem. 2009, 284, 25782-25790. [CrossRef]

127. Sadhu, K.; Hensley, K.; Florio, V.A.; Wolda, S.L. Differential expression of the cyclic GMP-stimulated phosphodiesterase PDE2A in human venous and capillary endothelial cells. J. Histochem. Cytochem. 1999, 47, 895-905. [CrossRef]

128. Aravind, L.; Ponting, C.P. The GAF domain: An evolutionary link between diverse phototransducing proteins. Trends Biochem. Sci. 1997, 22, 458-459. [CrossRef]

129. Martinez, S.E.; Wu, A.Y.; Glavas, N.A.; Tang, X.B.; Turley, S.; Hol, W.G.; Beavo, J.A. The two GAF domains in phosphodiesterase 2A have distinct roles in dimerization and in cGMP binding. Proc. Natl. Acad. Sci. USA 2002, 99, 13260-13265. [CrossRef]

130. Zaccolo, M.; Movsesian, M.A. cAMP and cGMP signaling cross-talk: Role of phosphodiesterases and implications for cardiac pathophysiology. Circ. Res. 2007, 100, 1569-1578. [CrossRef]

131. Mika, D.; Bobin, P.; Pomérance, M.; Lechêne, P.; Westenbroek, R.E.; Catterall, W.A.; Vandecasteele, G.; Leroy, J.; Fischmeister, R. Differential regulation of cardiac excitation-contraction coupling by cAMP phosphodiesterase subtypes. Cardiovasc. Res. 2013, 100, 336-346. [CrossRef] [PubMed]

132. Soler, F.; Fernández-Belda, F.; Pérez-Schindler, J.; Handschin, C.; Fuente, T.; Hernandez-Cascales, J. PDE2 activity differs in right and left rat ventricular myocardium and differentially regulates $\beta_{2}$ adrenoceptor-mediated effects. Exp. Biol. Med. 2014, 240, 1205-1213. [CrossRef] [PubMed]

133. Méry, P.-F.; Pavoine, C.; Pecker, F.; Fischmeister, R. Erythro-9-(2-hydroxy-3-nonyl)adenine inhibits cyclic GMP-stimulated phosphodiesterase in isolated cardiac myocytes. Mol. Pharmacol. 1995, 48, 121-130.

134. Mehel, H.; Emons, J.; Vettel, C.; Wittköpper, K.; Seppelt, D.; Dewenter, M.; Lutz, S.; Sossalla, S.; Maier, L.S.; Lechêne, P.; et al. Phosphodiesterase-2 Is Up-Regulated in Human Failing Hearts and Blunts $\beta$-Adrenergic Responses in Cardiomyocytes. J. Am. Coll. Cardiol. 2013, 62, 1596-1606. [CrossRef] [PubMed]

135. Subramanian, H.; Froese, A.; Jönsson, P.; Schmidt, H.; Gorelik, J.; Nikolaev, V.O. Distinct submembrane localisation compartmentalises cardiac NPR1 and NPR2 signalling to cGMP. Nat. Commun. 2018, 9, 2446. [CrossRef] [PubMed]

136. Rivet-Bastide, M.; Vandecasteele, G.; Hatem, S.; Verde, I.; Benardeau, A.; Mercadier, J.J.; Fischmeister, R. cGMP-stimulated cyclic nucleotide phosphodiesterase regulates the basal calcium current in human atrial myocytes. J. Clin. Investig. 1997, 99, 2710-2718. [CrossRef] [PubMed]

137. Dittrich, M.; Jurevičius, J.; Georget, M.; Rochais, F.; Fleischmann, B.K.; Hescheler, J.; Fischmeister, R. Local response of L-type $\mathrm{Ca}^{2+}$ current to nitric oxide in frog ventricular myocytes. J. Physiol. 2001, 534, 109-121. [CrossRef]

138. Vandecasteele, G.; Verde, I.; Rücker-Martin, C.; Donzeau-Gouge, P.; Fischmeister, R. Cyclic GMP regulation of the L-type $\mathrm{Ca}^{2+}$ channel current in human atrial myocytes. J. Physiol. 2001, 533, 329-340. [CrossRef]

139. Stangherlin, A.; Gesellchen, F.; Zoccarato, A.; Terrin, A.; Fields, L.A.; Berrera, M.; Surdo, N.C.; Craig, M.A.; Smith, G.; Ham-ilton, G.; et al. cGMP signals modulate cAMP levels in a compartment-specific manner to regulate catecholamine-dependent signaling in cardiac myocytes. Circ. Res. 2011, 108, 929-939. [CrossRef]

140. Fischmeister, R.; Hartzell, H.C. Cyclic guanosine $3^{\prime}, 5^{\prime}$-monophosphate regulates the calcium current in single cells from frog ventricle. J. Physiol. 1987, 387, 453-472. [CrossRef]

141. Perera, R.K.; Sprenger, J.U.; Steinbrecher, J.H.; Hubscher, D.; Lehnart, S.E.; Abesser, M.; Schuh, K.; El-Armouche, A.; Nikolaev, V.O. Microdomain switch of cGMP-regulated phosphodiesterases leads to ANP-induced augmentation of $\beta$-adrenoceptor-stimulated contractility in early cardiac hypertrophy. Circ. Res. 2015, 116, 1304-1311. [CrossRef] [PubMed]

142. Reinhardt, R.R.; Chin, E.; Zhou, J.; Taira, M.; Murata, T.; Manganiello, V.C.; Bondy, C.A. Distinctive anatomical patterns of gene expression for cGMP-inhibited cyclic nucleotide phosphodiesterases. J. Clin. Investig. 1995, 95, 1528-1538. [CrossRef] [PubMed]

143. Wechsler, J.; Choi, Y.H.; Krall, J.; Ahmad, F.; Manganiello, V.C.; Movsesian, M.A. Isoforms of cyclic nucleotide phosphodiesterase PDE3A in cardiac myocytes. J. Biol. Chem. 2002, 277, 38072-38078. [CrossRef] [PubMed]

144. Hambleton, R.; Krall, J.; Tikishvili, E.; Honeggar, M.; Ahmad, F.; Manganiello, V.C.; Movsesian, M.A. Isoforms of Cyclic Nucleotide Phosphodiesterase PDE3 and Their Contribution to cAMP Hydrolytic Activity in Subcellular Fractions of Human Myocardium. J. Biol. Chem. 2005, 280, 39168-39174. [CrossRef] 
145. Rascon, A.; Lindgren, S.; Stavenow, L.; Belfrage, P.; Andersson, K.E.; Manganiello, V.C.; Degerman, E. Purification and properties of the cGMP-inhibited cAMP phosphodiesterase from bovine aortic smooth muscle. Biochim. Biophys. Acta 1992, 1134, $149-156$. [CrossRef]

146. Chung, Y.W.; Lagranha, C.; Chen, Y.; Sun, J.; Tong, G.; Hockman, S.C.; Ahmad, F.; Esfahani, S.G.; Bae, D.H.; Polidovitch, N.; et al. Targeted disruption of PDE3B, but not PDE3A, protects murine heart from ischemia/reperfusion injury. Proc. Natl. Acad. Sci. USA 2015, 112, E2253-E2262. [CrossRef] [PubMed]

147. Shakur, Y.; Holst, L.S.; Landstrom, T.R.; Movsesian, M.; Degerman, E.; Manganiello, V. Regulation and function of the cyclic nucleotide phosphodiesterase (PDE3) gene family. Prog. Nucleic Acid Res. Mol. Biol. 2000, 66, 241-277. [CrossRef]

148. Palmer, D.; Jimmo, S.L.; Raymond, D.R.; Wilson, L.S.; Carter, R.L.; Maurice, D.H. Protein Kinase A Phosphorylation of Human Phosphodiesterase 3B Promotes 14-3-3 Protein Binding and Inhibits Phosphatase-catalyzed Inactivation. J. Biol. Chem. 2007, 282, 9411-9419. [CrossRef]

149. Ahmad, F.; Shen, W.; Vandeput, F.; Szabo-Fresnais, N.; Krall, J.; Degerman, E.; Goetz, F.; Klussmann, E.; Movsesian, M.; Manganiello, V. Regulation of sarcoplasmic reticulum $\mathrm{Ca}^{2+}$ ATPase 2 (SERCA2) activity by phosphodiesterase 3A (PDE3A) in human myocardium: Phosphorylation-dependent interaction of PDE3A1 with SERCA2. J. Biol. Chem. 2015, 290, $6763-6776$. [CrossRef]

150. Weishaar, R.E.; Kobylarz-Singer, D.C.; Steffen, R.P.; Kaplan, H.R. Subclasses of cyclic AMP-specific phosphodiesterase in left ventricular muscle and their involvement in regulating myocardial contractility. Circ. Res. 1987, 61, 539-547. [CrossRef]

151. Beca, S.; Ahmad, F.; Shen, W.; Liu, J.; Makary, S.; Polidovitch, N.; Sun, J.; Hockman, S.; Chung, Y.W.; Movsesian, M.; et al. Phosphodiesterase Type 3A Regulates Basal Myocardial Contractility Through Interacting with Sarcoplasmic Reticulum Calcium ATPase Type 2a Signaling Complexes in Mouse Heart. Circ. Res. 2013, 112, 289-297. [CrossRef] [PubMed]

152. Movsesian, M.A.; Smith, C.J.; Krall, J.; Bristow, M.R.; Manganiello, V.C. Sarcoplasmic reticulum-associated cyclic adenosine 5'-monophosphate phosphodiesterase activity in normal and failing human hearts. J. Clin. Investig. 1991, 88, 15-19. [CrossRef] [PubMed]

153. Christ, T.; Engel, A.; Ravens, U.; Kaumann, A.J. Cilostamide potentiates more the positive inotropic effects of (-)-adrenaline through $\beta_{2}$-adrenoceptors than the effects of $(-)$-noradrenaline through $\beta_{1}$-adrenoceptors in human atrial myocardium. Naunyn Schmiedebergs Arch. Exp. Pathol. Pharmakol. 2006, 374, 249-253. [CrossRef] [PubMed]

154. Eschenhagen, T. PDE4 in the human heart-Major player or little helper? Br. J. Pharmacol. 2013, 169, 524-527. [CrossRef]

155. Jurevicius, J.; Skeberdis, V.A.; Fischmeister, R. Role of cyclic nucleotide phosphodiesterase isoforms in cAMP compartmentation following $\beta_{2}$-adrenergic stimulation of $\mathrm{I}_{\mathrm{Ca}, \mathrm{L}}$ in frog ventricular myocytes. J. Physiol. 2003, 551, 239-252. [CrossRef]

156. Levy, F.O. Cardiac PDEs and crosstalk between cAMP and cGMP signalling pathways in the regulation of contractility. Naunyn Schmiedebergs Arch. Exp. Pathol. Pharmakol. 2013, 386, 665-670. [CrossRef]

157. Fujishige, K.; Kotera, J.; Michibata, H.; Yuasa, K.; Takebayashi, S.-I.; Okumura, K.; Omori, K. Cloning and Characterization of a Novel Human Phosphodiesterase That Hydrolyzes Both cAMP and cGMP (PDE10A). J. Biol. Chem. 1999, $274,18438-18445$. [CrossRef]

158. Soderling, S.H.; Bayuga, S.J.; Beavo, J.A. Isolation and characterization of a dual-substrate phosphodiesterase gene family: PDE10A. Proc. Natl. Acad. Sci. USA 1999, 96, 7071-7076. [CrossRef]

159. Loughney, K.; Snyder, P.; Uher, L.; Rosman, G.; Ferguson, K.; Florio, V. Isolation and characterization of PDE10A, a novel human 3', 5'-cyclic nucleotide phosphodiesterase. Gene 1999, 234, 109-117. [CrossRef]

160. McMurray, J.J.; Pfeffer, M.A. Heart failure. Lancet 2005, 365, 1877-1889. [CrossRef]

161. Mudd, J.O.; Kass, D.A. Tackling heart failure in the twenty-first century. Nature 2008, 451, 919-928. [CrossRef] [PubMed]

162. McDonagh, T.A.; Metra, M.; Adamo, M.; Gardner, R.S.; Baumbach, A.; Böhm, M.; Burri, H.; Butler, J.; Celutkiene, J.; Chioncel, O.; et al. 2021 ESC Guidelines for the diagnosis and treatment of acute and chronic heart failure. Eur. Heart J. 2021, 42, 3599-3726. [CrossRef] [PubMed]

163. Lohse, M.J.; Engelhardt, S.; Eschenhagen, T. What is the role of $\beta$-adrenergic signaling in heart failure? Circ. Res. 2003, 93, 896-906. [CrossRef] [PubMed]

164. Holmes, S.J.; Espiner, E.A.; Richards, A.M.; Yandle, T.; Frampton, C. Renal, endocrine, and hemodynamic effects of human brain natriuretic peptide in normal man. J. Clin. Endocrinol. Metab. 1993, 76, 91-96. [CrossRef] [PubMed]

165. Wegener, J.W.; Nawrath, H.; Wolfsgruber, W.; Kühbandner, S.; Werner, C.; Hofmann, F.; Feil, R. cGMP-Dependent Protein Kinase I Mediates the Negative Inotropic Effect of cGMP in the Murine Myocardium. Circ. Res. 2002, 90, 18-20. [CrossRef] [PubMed]

166. Takimoto, E.; Champion, H.C.; Li, M.; Belardi, D.; Ren, S.; Rodriguez, E.R.; Bedja, D.; Gabrielson, K.L.; Wang, Y.; Kass, D.A. Chronic inhibition of cyclic GMP phosphodiesterase 5A prevents and reverses cardiac hypertrophy. Nat. Med. 2005, 11, 214-222. [CrossRef]

167. Kuhn, M. Function and Dysfunction of Mammalian Membrane Guanylyl Cyclase Receptors: Lessons from Genetic Mouse Models and Implications for Human Diseases. In Handbook of Experimental Pharmacology; Springer: Berlin/Heidelber, Germany, 2009; pp. 47-69. [CrossRef]

168. Patrucco, E.; Domes, K.; Sbroggio, M.; Blaich, A.; Schlossmann, J.; Desch, M.; Rybalkin, S.D.; Beavo, J.A.; Lukowski, R.; Hofmann, F. Roles of cGMP-dependent protein kinase I (cGKI) and PDE5 in the regulation of Ang II-induced cardiac hypertrophy and fibrosis. Proc. Natl. Acad. Sci. USA 2014, 111, 12925-12929. [CrossRef] 
169. Michel, K.; Herwig, M.; Werner, F.; Spes, K.; Abeßer, M.; Schuh, K.; Dabral, S.; Mügge, A.; Baba, H.A.; Skryabin, B.V.; et al. C-type natriuretic peptide moderates titin-based cardiomyocyte stiffness. JCI Insight 2020, 5, e139910. [CrossRef]

170. Baliga, R.S.; Preedy, M.E.J.; Dukinfield, M.S.; Chu, S.M.; Aubdool, A.A.; Bubb, K.J.; Moyes, A.J.; Tones, M.A.; Hobbs, A.J. Phosphodiesterase 2 inhibition preferentially promotes NO/guanylyl cyclase/cGMP signaling to reverse the development of heart failure. Proc. Natl. Acad. Sci. USA 2018, 115, E7428-E7437. [CrossRef]

171. Ghofrani, H.A.; D’Armini, A.M.; Grimminger, F.; Hoeper, M.M.; Jansa, P.; Kim, N.H.; Mayer, E.; Simonneau, G.; Wilkins, M.R.; Fritsch, A.; et al. Riociguat for the treatment of chronic thromboembolic pulmonary hypertension. N. Engl. J. Med. 2013, 369, 319-329. [CrossRef]

172. Armstrong, P.W.; Pieske, B.; Anstrom, K.J.; Ezekowitz, J.; Hernandez, A.F.; Butler, J.; Lam, C.S.; Ponikowski, P.; Voors, A.A.; Jia, G.; et al. Vericiguat in Patients with Heart Failure and Reduced Ejection Fraction. N. Engl. J. Med. 2020, 382, 1883-1893. [CrossRef] [PubMed]

173. Mcmurray, J.J.V.; Packer, M.; Desai, A.S.; Gong, J.; Lefkowitz, M.P.; Rizkala, A.R.; Rouleau, J.L.; Shi, V.C.; Solomon, S.D.; Swedberg, K.; et al. Angiotensin-Neprilysin Inhibition versus Enalapril in Heart Failure. N. Engl. J. Med. 2014, 371, 993-1004. [CrossRef] [PubMed]

174. McMurray, J.J.V.; Jackson, A.M.; Lam, C.S.P.; Redfield, M.M.; Anand, I.S.; Ge, J.; Lefkowitz, M.P.; Maggioni, A.P.; Martinez, F.; Packer, M.; et al. Effects of sacubitril-valsartan versus valsartan in women compared with men with heart failure and preserved ejection fraction: Insights from PARAGON-HF. Circulation 2020, 141, 338-351. [CrossRef] [PubMed]

175. Krüger, M.; Kötter, S.; Grützner, A.; Lang, P.; Andresen, C.; Redfield, M.M.; Butt, E.; Dos Remedios, C.G.; Linke, W.A. Protein Kinase G Modulates Human Myocardial Passive Stiffness by Phosphorylation of the Titin Springs. Circ. Res. 2009, 104, 87-94. [CrossRef]

176. Sollie, S.J.; Moltzau, L.R.; Hernandez-Valladares, M.; Berven, F.; Levy, F.O.; Andressen, K.W. C-type natriuretic peptide increases titin phosphorylation and decreases passive stiffness in rat cardiomyocytes; Abstracts from the 8th International Conference on cGMP Generators, Effectors and Therapeutic Implications. BMC Pharmacol. Toxicol. 2017, 18 (Suppl. S1), 64.

177. Krüger, M.; Linke, W.A. Protein kinase-A phosphorylates titin in human heart muscle and reduces myofibrillar passive tension. J. Muscle Res. Cell Motil. 2006, 27, 435-444. [CrossRef]

178. van Heerebeek, L.; Borbély, A.; Niessen, H.; Bronzwaer, J.G.; van der Velden, J.; Stienen, G.; Linke, W.; Laarman, G.J.; Paulus, W.J. Myocardial Structure and Function Differ in Systolic and Diastolic Heart Failure. Circulation 2006, 113, 1966-1973. [CrossRef]

179. Borbély, A.; Falcão-Pires, I.; van Heerebeek, L.; Hamdani, N.; Édes, I.; Gavina, C.; Leite-Moreira, A.; Bronzwaer, J.G.; Papp, Z.; van der Velden, J.; et al. Hypophosphorylation of the Stiff N2B Titin Isoform Raises Cardiomyocyte Resting Tension in Failing Human Myocardium. Circ. Res. 2009, 104, 780-786. [CrossRef]

180. Yanaka, N.; Kurosawa, Y.; Minami, K.; Kawai, E.; Omori, K. cGMP-phosphodiesterase activity is up-regulated in response to pressure overload of rat ventricles. Biosci. Biotechnol. Biochem. 2003, 67, 973-979. [CrossRef]

181. Silver, P.J.; Allen, P.; Etzler, J.H.; Hamel, L.T.; Bentley, R.G.; Pagani, E.D. Cellular distribution and pharmacological sensitivity of low $\mathrm{Km}$ cyclic nucleotide phosphodiesterase isozymes in human cardiac muscle from normal and cardiomyopathic subjects. Second. Messengers Phosphoprot. 1990, 13, 13-25.

182. Smith, C.J.; Huang, R.; Sun, D.; Ricketts, S.; Hoegler, C.; Ding, J.Z.; Moggio, R.A.; Hintze, T.H. Development of decompensated dilated cardiomyopathy is associated with decreased gene expression and activity of the milrinone-sensitive cAMP phosphodiesterase PDE3A. Circulation 1997, 96, 3116-3123. [CrossRef]

183. Ding, B.; Abe, J.I.; Wei, H.; Huang, Q.; Walsh, R.A.; Molina, C.A.; Zhao, A.; Sadoshima, J.; Blaxall, B.C.; Berk, B.C.; et al. Functional role of phosphodiesterase 3 in cardiomyocyte apoptosis: Implication in heart failure. Circulation 2005, 111, 2469-2476. [CrossRef] [PubMed]

184. Abi-Gerges, A.; Richter, W.; Lefebvre, F.; Mateo, P.; Varin, A.; Heymes, C.; Samuel, J.-L.; Lugnier, C.; Conti, M.; Fischmeister, R.; et al. Decreased Expression and Activity of cAMP Phosphodiesterases in Cardiac Hypertrophy and Its Impact on $\beta$-Adrenergic cAMP Signals. Circ. Res. 2009, 105, 784-792. [CrossRef] [PubMed]

185. Takahashi, K.; Osanai, T.; Nakano, T.; Wakui, M.; Okumura, K. Enhanced activities and gene expression of phosphodiesterase types 3 and 4 in pressure-induced congestive heart failure. Heart Vessel. 2002, 16, 249-256. [CrossRef]

186. Holbrook, M.; Coker, S.J. Effects of zaprinast and rolipram on platelet aggregation and arrhythmias following myocardial ischaemia and reperfusion in anaesthetized rabbits. J. Cereb. Blood Flow Metab. 1991, 103, 1973-1979. [CrossRef] [PubMed]

187. Vandenwijngaert, S.; Pokreisz, P.; Hermans, H.; Gillijns, H.; Pellens, M.; Bax, N.; Coppiello, G.; Oosterlinck, W.; Balogh, A.; Papp, Z.; et al. Increased Cardiac Myocyte PDE5 Levels in Human and Murine Pressure Overload Hypertrophy Contribute to Adverse LV Remodeling. PLoS ONE 2013, 8, e58841. [CrossRef] [PubMed]

188. Senzaki, H.; Smith, C.J.; Juang, G.J.; Isoda, T.; Mayer, S.P.; Ohler, A.; Paolocci, N.; Tomaselli, G.F.; Hare, J.M.; Kass, D.A. Cardiac phosphodiesterase 5 (cGMP-specific) modulates $\beta$-adrenergic signaling in vivo and is down-regulated in heart failure. FASEB J. 2001, 15, 1718-1726. [CrossRef]

189. Pokreisz, P.; Vandenwijngaert, S.; Bito, V.; Van Den Bergh, A.; Lenaerts, I.; Busch, C.; Marsboom, G.; Gheysens, O.; Vermeersch P.; Biesmans, L.; et al. Ventricular phosphodiesterase- 5 expression is increased in patients with advanced heart failure and contributes to adverse ventricular remodeling after myocardial infarction in mice. Circulation 2009, 119, 408-416. [CrossRef]

190. Lu, Z.; Xu, X.; Hu, X.; Lee, S.; Traverse, J.H.; Zhu, G.; Fassett, J.; Tao, Y.; Zhang, P.; dos Remedios, C.; et al. Oxidative Stress Regulates Left Ventricular PDE5 Expression in the Failing Heart. Circulation 2010, 121, 1474-1483. [CrossRef] 
191. Zhang, M.; Takimoto, E.; Lee, D.-I.; Santos, C.X.; Nakamura, T.; Hsu, S.; Jiang, A.; Nagayama, T.; Bedja, D.; Yuan, Y.; et al. Pathological Cardiac Hypertrophy Alters Intracellular Targeting of Phosphodiesterase Type 5 From Nitric Oxide Synthase-3 to Natriuretic Peptide Signaling. Circulation 2012, 126, 942-951. [CrossRef]

192. Vettel, C.; Lindner, M.; Dewenter, M.; Lorenz, K.; Schanbacher, C.; Riedel, M.; Lammle, S.; Meinecke, S.; Mason, F.E.; Sossalla, S.; et al. Phosphodiesterase 2 protects against catecholamine-induced arrhythmia and preserves contractile function after myocardial infarction. Circ. Res. 2017, 120, 120-132. [CrossRef]

193. Vettel, C.; Lämmle, S.; Ewens, S.; Cervirgen, C.; Emons, J.; Ongherth, A.; Dewenter, M.; Lindner, D.; Westermann, D.; Nikolaev, V.O.; et al. PDE2-mediated cAMP hydrolysis accelerates cardiac fibroblast to myofibroblast conversion and is antagonized by exogenous activation of cGMP signaling pathways. Am. J. Physiol. Circ. Physiol. 2014, 306, H1246-H1252. [CrossRef] [PubMed]

194. Lu, D.; Aroonsakool, N.; Yokoyama, U.; Patel, H.H.; Insel, P.A. Increase in cellular cyclic AMP concentrations reverses the profibrogenic phenotype of cardiac myofibroblasts: A novel therapeutic approach for cardiac fibrosis. Mol. Pharmacol. 2013, 84, 787-793. [CrossRef]

195. Sassi, Y.; Ahles, A.; Truong, D.-J.J.; Baqi, Y.; Lee, S.-Y.; Husse, B.; Hulot, J.-S.; Foinquinos, A.; Thum, T.; Müller, C.E.; et al. Cardiac myocyte-secreted cAMP exerts paracrine action via adenosine receptor activation. J. Clin. Investig. 2014, 124, 5385-5397. [CrossRef] [PubMed]

196. Koser, F.; Loescher, C.; Linke, W.A. Posttranslational modifications of titin from cardiac muscle: How, where, and what for? FEBS J. 2019, 286, 2240-2260. [CrossRef]

197. Bubb, K.J.; Trinder, S.L.; Baliga, R.S.; Patel, J.; Clapp, L.H.; MacAllister, R.J.; Hobbs, A.J. Inhibition of Phosphodiesterase 2 Augments cGMP and cAMP Signaling to Ameliorate Pulmonary Hypertension. Circulation 2014, 130, 496-507. [CrossRef] [PubMed]

198. Zoccarato, A.; Surdo, N.C.; Aronsen, J.M.; Fields, L.A.; Mancuso, L.; Dodoni, G.; Stangherlin, A.; Livie, C.; Jiang, H.; Sin, Y.Y.; et al. Cardiac Hypertrophy Is Inhibited by a Local Pool of cAMP Regulated by Phosphodiesterase Circ. Res. 2015, 117, 707-719. [CrossRef]

199. Dibianco, R.; Shabetai, R.; Kostuk, W.; Moran, J.; Schlant, R.C.; Wright, R. A Comparison of Oral Milrinone, Digoxin, and Their Combination in the Treatment of Patients with Chronic Heart Failure. N. Engl. J. Med. 1989, 320, 677-683. [CrossRef] [PubMed]

200. Cuffe, M.S.; Califf, R.M.; Adams Jr, K.F.; Benza, R.; Bourge, R.; Colucci, W.S.; Massie, B.M.; O'Connor, C.M.; Pina, I.; Quigg, R. Short-term intravenous milrinone for acute exacerbation of chronic heart failure: A randomized controlled trial. JAMA 2002, 287, 1541-1547. [CrossRef]

201. Bristow, M.R.; Ginsburg, R.; Minobe, W.; Cubicciotti, R.S.; Sageman, W.S.; Lurie, K.; Billingham, M.E.; Harrison, D.C.; Stinson, E.B. Decreased Catecholamine Sensitivity and $\beta$-Adrenergic-Receptor Density in Failing Human Hearts. N. Engl. J. Med. 1982, 307, 205-211. [CrossRef]

202. Amsallem, E.; Kasparian, C.; Haddour, G.; Boissel, J.-P.; Nony, P. Phosphodiesterase III inhibitors for heart failure. Cochrane Database Syst. Rev. 2005. [CrossRef] [PubMed]

203. Nanayakkara, S.; Byrne, M.; Mak, V.; Carter, K.; Dean, E.; Kaye, D.M. Extended-Release Oral Milrinone for the Treatment of Heart Failure with Preserved Ejection Fraction. J. Am. Heart Assoc. 2020, 9, e015026. [CrossRef] [PubMed]

204. Sun, B.; Li, H.; Shakur, Y.; Hensley, J.; Hockman, S.; Kambayashi, J.; Manganiello, V.C.; Liu, Y. Role of phosphodiesterase type 3A and 3B in regulating platelet and cardiac function using subtype-selective knockout mice. Cell. Signal. 2007, 19, $1765-1771$. [CrossRef] [PubMed]

205. Johnson, W.; Katugampola, S.; Able, S.; Napier, C.; Harding, S. Profiling of cAMP and cGMP phosphodiesterases in isolated ventricular cardiomyocytes from human hearts: Comparison with rat and guinea pig. Life Sci. 2012, 90, 328-336. [CrossRef]

206. Karam, S.; Margaria, J.P.; Bourcier, A.; Mika, D.; Varin, A.; Bedioune, I.; Lindner, M.; Bouadjel, K.; Dessillons, M.; Gaudin, F.; et al. Cardiac Overexpression of PDE4B Blunts $\beta$-Adrenergic Response and Maladaptive Remodeling in Heart Failure. Circulation 2020, 142, 161-174. [CrossRef]

207. Nagendran, J.; Archer, S.L.; Soliman, D.; Gurtu, V.; Moudgil, R.; Haromy, A.; Aubin, C.S.; Webster, L.; Rebeyka, I.M.; Ross, D.B.; et al. Phosphodiesterase Type 5 Is Highly Expressed in the Hypertrophied Human Right Ventricle, and Acute Inhibition of Phosphodiesterase Type 5 Improves Contractility. Circulation 2007, 116, 238-248. [CrossRef]

208. Shan, X.; Quaile, M.P.; Monk, J.K.; French, B.; Cappola, T.P.; Margulies, K.B. Differential Expression of PDE5 in Failing and Nonfailing Human Myocardium. Circ. Heart Fail. 2012, 5, 79-86. [CrossRef]

209. Garcia, A.M.; Nakano, S.J.; Karimpour-Fard, A.; Nunley, K.; Blain-Nelson, P.; Stafford, N.M.; Stauffer, B.L.; Sucharov, C.C.; Miyamoto, S.D. Phosphodiesterase-5 is elevated in failing single ventricle myocardium and affects cardiomyocyte remodeling in vitro. Circ. Heart Fail. 2018, 11, e004571. [CrossRef]

210. Zhang, M.; Koitabashi, N.; Nagayama, T.; Rambaran, R.; Feng, N.; Takimoto, E.; Koenke, T.; O’Rourke, B.; Champion, H.C.; Crow, M.T.; et al. Expression, activity, and pro-hypertrophic effects of PDE5A in cardiac myocytes. Cell. Signal. 2008, 20, 2231-2236. [CrossRef]

211. Huang, C.-K.; Chen, B.-Y.; Guo, A.; Chen, R.; Zhu, Y.-Q.; Kutschke, W.; Hong, J.; Song, L.-S. Sildenafil ameliorates left ventricular T-tubule remodeling in a pressure overload-induced murine heart failure model. Acta Pharmacol. Sin. 2016, 37, 473-482. [CrossRef]

212. Lawless, M.; Caldwell, J.L.; Radcliffe, E.J.; Smith, C.E.R.; Madders, G.W.P.; Hutchings, D.C.; Woods, L.S.; Church, S.J.; Unwin, R.D.; Kirkwood, G.J.; et al. Phosphodiesterase 5 inhibition improves contractile function and restores transverse tubule loss and catecholamine responsiveness in heart failure. Sci. Rep. 2019, 9, 6801. [CrossRef] 
213. Lewis, G.D.; Shah, R.; Shahzad, K.; Camuso, J.M.; Pappagianopoulos, P.P.; Hung, J.; Tawakol, A.; Gerszten, R.E.; Systrom, D.; Bloch, K.D.; et al. Sildenafil Improves Exercise Capacity and Quality of Life in Patients With Systolic Heart Failure and Secondary Pulmonary Hypertension. Circulation 2007, 116, 1555-1562. [CrossRef]

214. Guazzi, M.; Vicenzi, M.; Arena, R.; Guazzi, M.D. Pulmonary hypertension in heart failure with preserved ejection fraction: A target of phosphodiesterase-5 inhibition in a 1-year study. Circulation 2011, 124, 164-174. [CrossRef] [PubMed]

215. Redfield, M.M.; Chen, H.H.; Borlaug, B.A.; Semigran, M.J.; Lee, K.L.; Lewis, G.; Lewinter, M.M.; Rouleau, J.L.; Bull, D.A.; Mann, D.L.; et al. Effect of phosphodiesterase-5 inhibition on exercise capacity and clinical status in heart failure with preserved ejection fraction: A randomized clinical trial. JAMA 2013, 309, 1268-1277. [CrossRef] [PubMed]

216. Zhuang, X.-D.; Long, M.; Li, F.; Hu, X.; Liao, X.-X.; Du, Z.-M. PDE5 inhibitor sildenafil in the treatment of heart failure: A meta-analysis of randomized controlled trials. Int. J. Cardiol. 2014, 172, 581-587. [CrossRef] [PubMed]

217. De Vecchis, R.; Cesaro, A.; Ariano, C.; Giasi, A.; Cioppa, C. Phosphodiesterase-5 Inhibitors Improve Clinical Outcomes, Exercise Capacity and Pulmonary Hemodynamics in Patients with Heart Failure with Reduced Left Ventricular Ejection Fraction: A Meta-Analysis. J. Clin. Med. Res. 2017, 9, 488-498. [CrossRef] [PubMed]

218. Dunkerly-Eyring, B.; Kass, D.A. Myocardial Phosphodiesterases and Their Role in cGMP Regulation. J. Cardiovasc. Pharmacol. 2020, 75, 483-493. [CrossRef]

219. Shah, S.J.; Kitzman, D.W.; Borlaug, B.A.; Van Heerebeek, L.; Zile, M.R.; Kass, D.A.; Paulus, W.J. Phenotype-specific treatment of heart failure with preserved ejection fraction: A multiorgan roadmap. Circulation 2016, 134, 73-90. [CrossRef]

220. Richards, D.A.; Aronovitz, M.J.; Liu, P.; Martin, G.L.; Tam, K.; Pande, S.; Karas, R.H.; Bloomfield, D.M.; Mendelsohn, M.E.; Blanton, R.M. CRD-733, a novel PDE9 (phosphodiesterase 9) inhibitor, reverses pressure overload-induced heart failure. Circ. Heart Fail. 2021, 14, e007300. [CrossRef]

221. Zaccolo, M.; Zerio, A.; Lobo, M.J. Subcellular Organization of the cAMP Signaling Pathway. Pharmacol. Rev. 2020, 73, 278-309. [CrossRef]

222. Koschinski, A.; Zaccolo, M. Activation of PKA in cell requires higher concentration of cAMP than in vitro: Implications for compartmentalization of cAMP signalling. Sci. Rep. 2017, 7, 14090. [CrossRef] [PubMed]

223. Øgreid, D.; Døskeland, S.O. Activation of protein kinase isoenzymes under near physiological conditions. Evidence that both types (A and B) of cAMP binding sites are involved in the activation of protein kinase by cAMP and 8-N3-cAMP. FEBS Lett. 1982, 150, 161-166. [CrossRef]

224. Adams, S.R.; Harootunian, A.T.; Buechler, Y.J.; Taylor, S.S.; Tsien, R.Y. Fluorescence ratio imaging of cyclic AMP in single cells. Nature 1991, 349, 694-697. [CrossRef] [PubMed]

225. Iancu, R.V.; Ramamurthy, G.; Warrier, S.; Nikolaev, V.O.; Lohse, M.J.; Jones, S.W.; Harvey, R.D. Cytoplasmic cAMP concentrations in intact cardiac myocytes. Am. J. Physiol. Physiol. 2008, 295, C414-C422. [CrossRef]

226. Nikolaev, V.O.; Bünemann, M.; Hein, L.; Hannawacker, A.; Lohse, M.J. Novel single chain cAMP sensors for receptor-induced signal propagation. J. Biol. Chem. 2004, 279, 37215-37218. [CrossRef]

227. Richards, M.; Lomas, O.; Jalink, K.; Ford, K.L.; Vaughan-Jones, R.D.; Lefkimmiatis, K.; Swietach, P. Intracellular tortuosity underlies slow cAMP diffusion in adult ventricular myocytes. Cardiovasc. Res. 2016, 110, 395-407. [CrossRef]

228. McCabe, K.J.; Rangamani, P. Computational modeling approaches to cAMP/PKA signaling in cardiomyocytes. J. Mol. Cell. Cardiol. 2021, 154, 32-40. [CrossRef]

229. Bock, A.; Annibale, P.; Konrad, C.; Hannawacker, A.; Anton, S.E.; Maiellaro, I.; Zabel, U.; Sivaramakrishnan, S.; Falcke, M.; Lohse, M.J. Optical Mapping of cAMP Signaling at the Nanometer Scale. Cell 2020, 182, 1519-1530.e17. [CrossRef]

230. Zhang, J.Z.; Lu, T.-W.; Stolerman, L.M.; Tenner, B.; Yang, J.R.; Zhang, J.-F.; Falcke, M.; Rangamani, P.; Taylor, S.S.; Mehta, S.; et al Phase Separation of a PKA Regulatory Subunit Controls cAMP Compartmentation and Oncogenic Signaling. Cell 2020, 182, 1531-1544.e15. [CrossRef] 